УДК 553.435

\title{
МИНЕРАЛОГО-ГЕОХИМИЧЕСКИЕ ОСОБЕННОСТИ ХАЛЬКОПИРИТА РУД ЮБИЛЕЙНОГО МЕДНОКОЛЧЕДАННОГО МЕСТОРОЖДЕНИЯ (ЮЖНЫЙ УРАЛ) ПО ДАННЫМ ЛА-ИСП-МС
}

\author{
Целуйко Александр Сергеевич1, \\ celyukoa@rambler.ru
}

\author{
Масленников Валерий Владимирович1, \\ mas@mineralogy.ru
}

\author{
Аюпова Нурия Радитовна ${ }^{1}$, \\ aupova@mineralogy.ru
}
Масленникова Светлана Петровна ${ }^{1}$, svmas@mineralogy.ru

Артемьев Дмитрий Александрович1,
artemyev@mineralogy.ru

\author{
Блинов Иван Александрович 1 , \\ Ivan_a_blinov@mail.ru \\ 1 Южно-Уральский федеральный научный центр минералогии и геоэкологии УрО РАН, \\ Россия, 456317, г. Миасс, территория Ильменского заповедника.
}

\begin{abstract}
Актуальность. Исследования сульфидов методом ЛА-ИСП-МС является одним из перспективных направлений изучения рудных месторождений. Понимание трендов минералого-геохимической эволюции сульфидов позволяет интерпретировать процессы дифрреренциации вещества на стадиях гидротермального седиментогенеза и литогенеза колчеданных месторождений, что актуально для создания и развития минералого-геохимических моделей сульфидного аутигенеза на новом уровне. Цель: сопоставление минералого-геохимической специализации генетических разновидностей халькопирита для выявления тренда эволюции сульфидных отложений Юбилейного медноколчеданного месторождения (Южный Урал).

Методы. Выявление морфогенетических типов халькопирита проводилось на основе рудно-фациальных исследований. Изучение минеральных особенностей халькопирита выполнено на оптическом микроскопе Olymриs BX51. Состав редких минералов получен с помощью сканирующего электронного микроскоna Tescan Vega 3 sbu. Coдержания элементов-примесей в халькопирите получены методом ЛА-ИСП-МС на масс-спектрометре Agilent 7700x, оборудованного приставкой для лазерной абляции New Wave Research UP-213 в ЮУ ФНЦ МиГ УрО РАН. Предварительные ЛА-ИСП-МС анализы халькопирита сделаны в Тасманийском университете (2. Хобарт, Австралия).

Результаты. Разновидности халькопирита подразделены на две группы: гидротермальную и постседиментационную. Гидротермальная группа включает в себя субгедральные разновидности халькопирита пирит-халькопиритовых, сфралеритпирит-халькопиритовых, и халькопирит-пирит-сфралеритовых труб палеокурильщиков. Во второй группе, сформированной по рудокластитам, выделены псевдоморфные, цементационные, конкреционные, а также прожилковые динамометаморфические разновидности халькопирита. Каждая разновидность халькопирита характеризуется своими минеральными ассоциациями и вариациями содержаний элементов-примесей, отражающими различия в процессах и условиях минералообразования. В ряду от пирит-халькопиритовых к существенно сфралеритовым гидротермальным трубам палеокурильщиков наблюдается смена копьевидных и дендритовидных кристаллов халькопирита графическими и эпитаксиальными сростками халькопирита и сфралерита. В этом же направлении в гидротермальном халькопирите снижаются медианнье содержания элементов высокотемпературной (Se, Bi), среднетемпературной (Te, Sb) и низкотемпературной (TI) ассоциаций. Постседиментационные разновидности халькопирита отличаются от гидротермальных аналогов пониженными концентрациями Sn и отсутствием существенных вариаций содержаний Sе. Во временном ряду постседиментационного халькопирита (псевдоморфный $\rightarrow$ цементационный $\rightarrow$ конкреционные $\rightarrow$ прожилковый) постепенно убывают медианные значения содержаний примесей Мn, Co, Ni, Mo, As, Tl, Au, Ag, Bi u Te.
\end{abstract}

\section{Ключевые слова:}

Халькопирит, аутигенез, ЛА-ИСП-МС, трубы палеокурильщиков, сульфридные турбидиты, сульфидные конкреции, колчеданные месторождения, Южный Урал.

\section{Введение}

В рудах колчеданных месторождений Урала халькопирит является третьим по распространенности рудным минералом и главным источником меди [1]. Являясь сквозным минералом в большинстве типов колчеданных руд, халькопирит образуется в широком диапазоне условий. Предполагается, что формирование халькопирита начинается с образования крусти- фикационного халькопирита в гидротермальную стадию и продолжается при постседиментационных преобразованиях руд [1-5 и др.].

Ключом для типизации генераций халькопирита может выступать полноценная текстурно-структурная, морфологическая и геохимическая характеристика, выполненная с учетом времени, обстановок и процессов минералообразования применительно к опреде- 
ленным рудным фациям. Первичный гидротермальный халькопирит, обнаруженный в фрагментах сульфидных труб колчеданных месторождений, имеет копьевидную морфологию и содержит решетчатые структуры распада, характерные для высокотемпературного халькопирита современных черных курильщиков $[3,6,7]$. Вторичный псевдоморфный халькопирит распространен в рудокластических отложениях месторождений уральского типа, где он, благодаря большей устойчивости в условиях субмаринного гипергенеза, замещает пирит и сфалерит [4, 8-10]. Придонный характер замещения халькопиритом подтверждается ассиметричной минералогической 30нальностью сульфидных слоев, в кровле которых помимо новообразованного халькопирита концентрируются оксиды железа, кварц и/или барит [4, 8-10]. Для некоторых халькопиритовых руд, например, на Сафьяновском месторождении, предполагается гидротермально-метасоматическое происхождение [5].

Благодаря относительно низким содержаниям большинства элементов-примесей в халькопирите, подходящим методом для его изучения является масс-спектрометрия с индуктивно связанной плазмой и лазерной абляцией (ЛА-ИСП-МС). Исследование типохимизма халькопирита рудных месторождений методом ЛА-ИСП-МС - перспективное направление исследований, активно развивающееся в последнее время [11-18]. При этом изучению химического состава гидротермального высокотемпературного халькопирита уделяется гораздо больше внимания по сравнению с постседиментационными новообразованными разновидностями. Отмечается, что гидротермально-крустификационный халькопирит относительно псевдоморфной разновидности обогащен большей частью элементов-примесей $[4,5]$. Вместе с тем концентрации химических элементов в псевдоморфном халькопирите крайне непостоянны и зависят от геохимических ассоциаций замещаемых сульфидов $[4,5]$. Информативными могут оказаться прожилковые, цементационные и конкреционные разновидности халькопирита, так как именно они отражают особенности геохимической дифференциации в поздние стадии преобразования колчеданных руд. Подходящим объектом для исследований выступают обломочные сульфидные отложения, комбинирующие в себе совокупность рудокластических, псевдоморфных, интерстициальных, цементационных, прожилковых и конкреционных разновидностей халькопирита. Сравнительный анализ халькопирита различного генезиса открывает путь к пониманию минералого-геохимической эволюции сульфидных отложений.

В статье на примере сульфидных отложений Юбилейного месторождения проведено сопоставление гидротермальных и постседиментационных разновидностей халькопирита с целью выявления тренда минералого-геохимической эволюции, что может быть использовано для реконструкции сульфидной залежи от стадий гидротермального рудоотложения до субмаринного гипергенеза. Фундаментальная ценность подобных исследований состоит в интерпрета- ции процессов дифференциации вещества на различных стадиях седиментогенеза и литогенеза колчеданных месторождений. Изучение особенностей микроэлементного состава постседиментационных сульфидов необходимо для выявления критериев отличия рудоносных и безрудных горизонтов колчеданоносных полей и может быть использовано как один из поисковых признаков на колчеданное оруденение при разведочных работах.

\section{Геологическая характеристика месторождения}

Юбилейное медноколчеданное месторождение географически расположено в 34 км к северу от с. Акъяр (Башкортостан). Месторождение приурочено к Западно-Магнитогорской палеовулканической зоне, колчеданоносные комплексы которой принадлежат фронтальной части энсиматической островодужной системы $[19,20]$. Шесть рудных залежей месторождения локализованы в породах баймак-бурибайской свиты, соответствующей раннедевонскому начальному циклу островодужного вулканизма ( $\left.\mathrm{D}_{1} e_{2} \mathrm{~b}-\mathrm{br}\right)$ и перекрыты породами верхнетаналыкского комплекса (D2e2vtn): базальтами, андезибазальтами, андезитами, дацитами, риодацитами и риолитами гомодромной известково-щелочной серии (рис. 1) [21]. В составе рудовмещающей толщи распространены натриевые магнезиальные базальты, бонинито-базальты, бониниты, андезибониниты, магнезиальные андезиты и андезидациты [22].

Запасы руд месторождения достигают 107 млн т, меди - 1655 тыс. т, цинка - 1059 тыс. т. Средние содержания меди в различных промышленных сортах руд на месторождении составляют 0,08-5,74 \%, цинка - от 0,05 до 3,36 \%. Месторождение относится к уральскому типу колчеданных месторождений [23]. В настоящее время ведется подземная отработка руд Первой, Четвертой и Пятой залежей.

На месторождении встречены массивные, обломочные, обломковидные, прожилковые и слоистые руды, состоящие из пирита, халькопирита и сфалерита. Редкие минералы представлены марказитом, пирротином, арсенопиритом, галенитом, а также минералами группы блеклых руд, борнитом, магнетитом, гематитом, баритом, электрумом, самородным золотом, аргентитом, алтаитом, гесситом, колорадоитом, петцитом, теллуровисмутитом, раклиджитом, волынскитом, энаргитом, бурнонитом и германитом [19, 24, 25].

Рассматриваемые в статье руды локализованы преимущественно на флангах Второй рудной залежи, сложенных рудокластическими отложениями: сульфидными брекчиями и гравийно-песчаными и алевропесчаными сульфидными турбидитами. Горизонты обломочных руд переслаиваются с сульфидсодержащими кремнистыми и хлорит-кремнистыми алевропелитами. Среди рудокластов в центральной и периферийной части рудной залежи встречаются фрагменты сульфидных труб палеокурильщиков различного минерального состава и пиритизированные биоморфозы по мелким трубчатым червям [25]. 

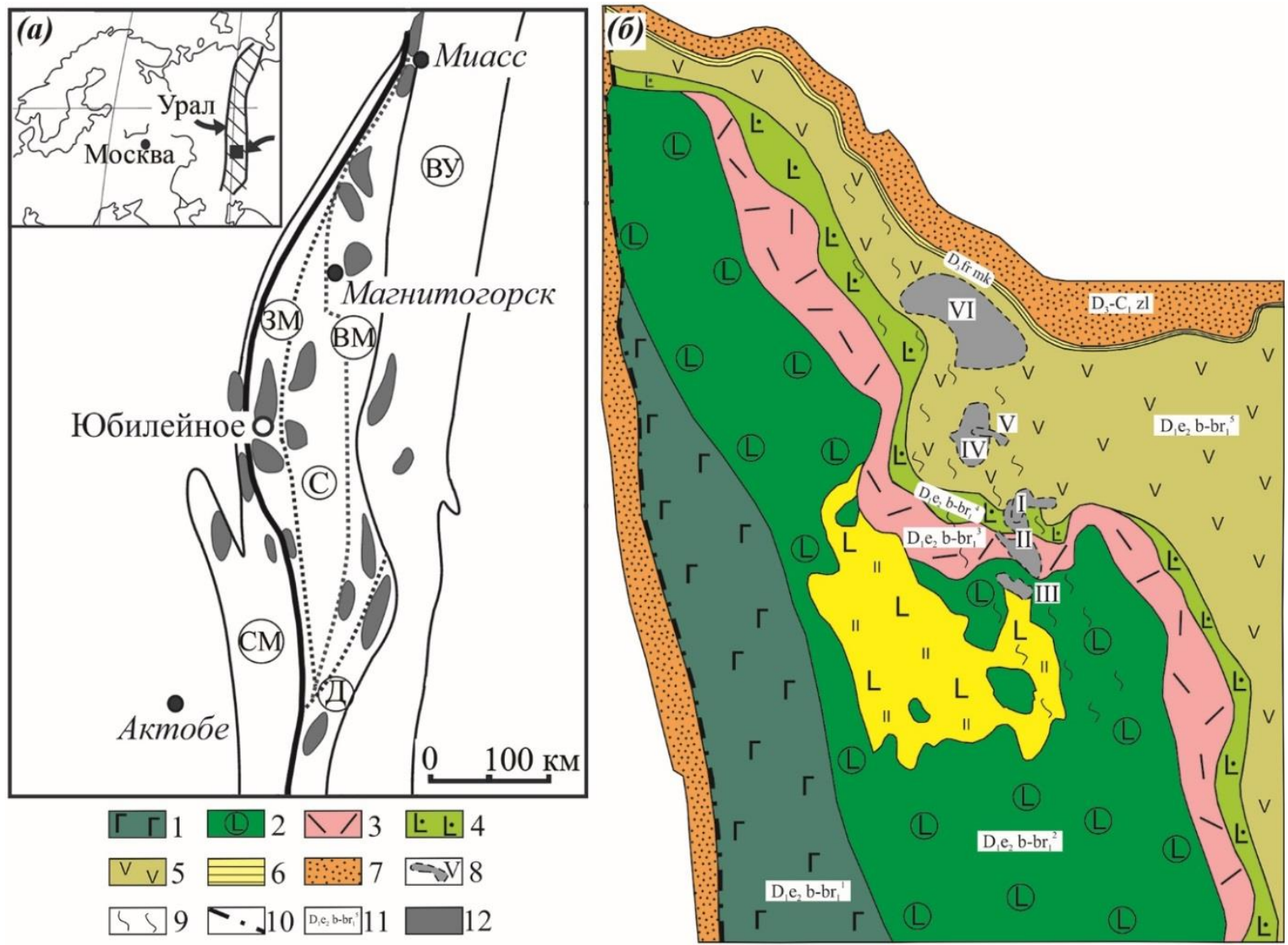

Pис. 1. Позиция месторождения на схеме палеогеодинамических зон Южного Урала (а) и схематическая геологическая карта Юбилейного медноколчеданного месторождения (б) [9, 19]. ГУР - Главный Уральский разлом, ВМ - Восточно-Магнитогорская дуга, ЗМ - Западно-Магнитогорская дуга, ВУ - Восточно-Уральское поднятие, С-Сибайский междуговой бассейн, Д-Домбаровский задуговой бассейин, СМ - Сакмарское окраинное море; 1 - диабазы; 2 - базальты; 3 - дациты и риодациты; 4 - лавы андезито-базальтового состава; 5 - андезиты и андезито-дациты; 6 - кремнистые породы Мукасовкого горизонта; 7 - полимиктовые песчаники зилаирской свиты; 8 - горизонтальные проекиии рудных залежей и их номера; 9 - зоны дробления и рассланцевания; 10 - разрывные нарушения; 11 - название геологических свит

Fig. 1. Position of Yubileynoe VMS deposit in paleogeodynamic regions of South Urals (a), schema of open pit (b) and geological cross-section of Second ore body (c) [9, 19]. ГУP - main Ural fault, BM - East Magnitogorsk arc, 3MWest Magnitogorsk arc, BУ - East Uralian uplift, C - Sibai inter-arc basin, Д-Dombarovka back arc basin; CM Sakmara marginal sea; 1 - diabases; 2 - basalts; 3 -dacites and rhyodacites; 4 - lavas of andesite-basalt composition; 5 - andesite and andesite-dacites; 6 - siliceous rocks of the Mukasovskogo horizon; 7 - polymictic sandstones of the Zilairskoy formation; 8 - horizontal projections of ore deposits and their numbers; 9 - zones of crushing; 10 -fracture violations; 11 - the name of geological formations

\section{Методы исследований}

Для исследований использовался материал, отобранный в ходе полевых работ в карьере Юбилейного месторождения. Среди штуфных образцов размером до $30 * 20$ см выделены наиболее обогащенные халькопиритом. Оптические исследования минералов проводились на микроскопе Olympus BX51. Внутреннее строение агрегатов халькопирита выявлялось с помощью травления раствором $\mathrm{HCl}+\mathrm{HNO}_{3}$. Диагностика редких минералов проведена с помощью сканирующего электронного микроскопа Tescan Vega 3 sbu с энергодисперсионным анализатором Oxford Instruments X-act (Институт минералогии ЮУ ФНЦ МиГ УрО РАН, аналитик И.А. Блинов). Предел обнаружения химических элементов не превышают 0,2 мас. \%. Воспроизводимость определений составляет от 1 до 15 отн. \%.
Содержания элементов-примесей в халькопирите конкреций и сульфидных турбидитов получены методом ЛА-ИСП-МС на масс-спектрометре Agilent 7700x, оборудованном приставкой для лазерной абляции New Wave Research UP-213, в Институте минералогии ЮУ ФНЦ МиГ УрО РАН (аналитик Д.А. Артемьев). Диаметр лазерного пучка составлял 40-60 мкм, частота 5 Гц, энергия на поверхности образца 4-5 Дж/см². Время анализа составляло 100 с, из которых 30 с занимало измерение фона. Для градуировки и расчета использовались международные стандарты: прессованный сульфид USGS MASS-1 и стекло USGS GSD-1g. Несущий газ - Не 0,6 л/мин и $\operatorname{Ar} 0,95$ л/мин. Расчет проводился в программе Iolite c использованием ${ }^{57} \mathrm{Fe}$ в качестве внутреннего стандарта. Результаты анализов обработаны с использовани- 
ем программ Excel 2016 и Statistica и представлены в виде таблиц и диаграмм «box\&whiskers», на которых показаны квантили 25 и 75 \%, медианные и ураганные значения содержаний элементов.

Дополнительные ЛА-ИСП-МС анализы халькопирита выполнены в Тасманийском университете (г. Хобарт, Австралия, аналитики В.В. Масленников, С.П. Масленникова) на лазерном микрозонде New Wave Research UP-213, соединенном с массспектрометром Agilent 7700x. Подробно методика ЛА-ИСП-МС анализов описана в работе [26].

\section{Результаты исследований}

Халькопирит гидротермальных труб

Гидротермальные трубы палеокурильщиков являются аналогами современных черных курильщиков и маркируют выходы высокотемпературных минерализованных растворов на поверхность морского дна. Характерными чертами труб как современных, так и древних черных курильщиков является концентрически-зональное строение, округлая или овальная форма в поперечном сечении и небольшой диаметр (до 3-4 см) одиночных трубок. Условия высокого градиента температур формирования труб обуславливают неоднородные текстурно-структурные и геохи- мические характеристики гидротермального халькопирита [11, 12 и др.].

В колчеданных рудах Юбилейного месторождения первичный гидротермальный халькопирит участвует в строении внутренних стенок палеокурильщиков пиритхалькопиритового, сфалерит-пирит-халькопиритового и халькопирит-пирит-сфалеритового состава (рис. 2, a-8). Халькопиритовая стенка сульфидных труб обычно состоит из трех подзон: (1) внешней, контактирующей c оболочкой и содержащей включения эвгедральных зерен пирита, сфалерита и нерудных минералов (рис. 2, г); (2) центральной, в которой преобладают сростки копьевидных кристаллов размером до 1-2 мм и более (рис. 2, 2 ) и (3) внутренней, граничащей с осевым каналом и образованной друзовидными зернами халькопирита и сфалерита, часто с кальцитом и кварцем в интерстициях (рис. 2, е). В некоторых трубах центральная халькопиритовая подзона отсутствует, а другие подзоны развиты неравномерно и часто прерываются. В целом строение халькопиритовой стенки труб палеокурильщиков Юбилейного месторождения во многом напоминает аналогичные зоны в трубах современных гидротермальных построек [12, 27 и др.].
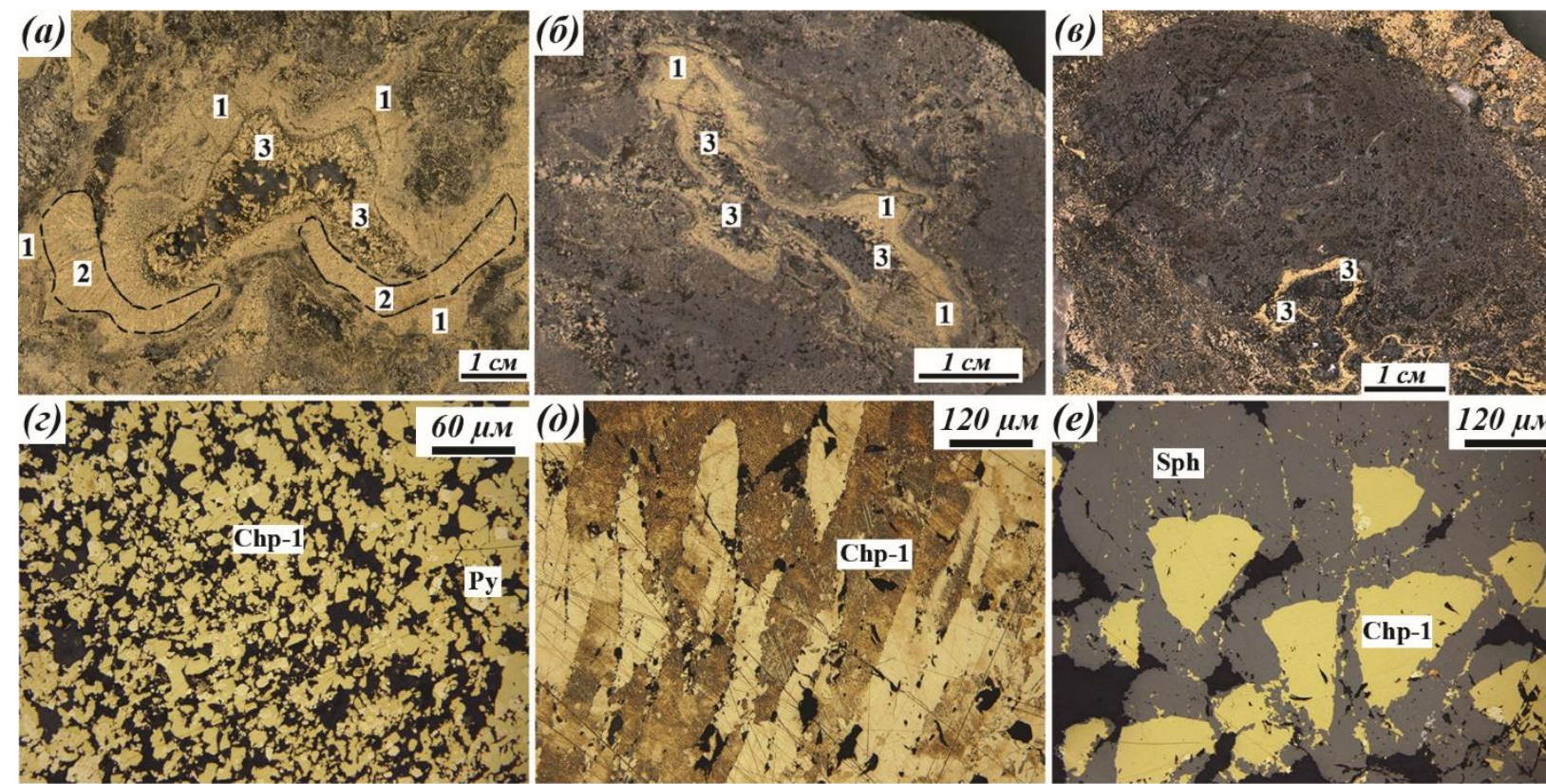

Рис. 2. Трубы палеокурильщчиков в рудах Юбилейного месторождения: квари-пирит-халькопиритовая (а), тальксфалерит-пирит-халькопиритовая (б), халькопирит-пирит-сфалеритовая (в) (1 - мелкозернистьй халькопирит внешней зоны, 2 -копьевидные кристаллы халькопирита в центральной подзоне (обведена пунктирной линией) и 3 - друзовидные зерна халькопирита во внутренней подзоне); г) мелкозернистый гидротермальный халькопирит (Сhp-1) с включениями пирита (Pу) в кварцевом ичементе; д) копьевиднье кристалль халькопирита (Chp-1) в центральной подзоне; е) друзовиднье кристалль халькопирита (Chр-1), обрастающие каймами сфалерита (Sph) во внешней подзоне. Фото: а-в полированный образеи, г-е - отраженный свет, дпротравлено в $\mathrm{HNO}_{3}+\mathrm{HCl}$

Fig. 2. Chimneys of paleosmokers in ores of Yubileynoe deposit: chalcopyrite-pyrite-quartz (a), chalcopyrite-pyritesphalerite-talc (б), sphalerite-pyrite-chalcopyrite (в) (1 - fine-grained chalcopyrite of the outer subzone, 2 -lanceshaped crystals of chalcopyrite in the central subzone (circled by a dotted line) and 3 -druse grains of chalcopyrite in the inner subzone); 2) fine-grained hydrothermal chalcopyrite (Chp-1) with pyrite (Py) inclusions in quartz cement; d) lance-shaped chalcopyrite crystals (Chp-1) in the central subzone; e) druse crystals of chalcopyrite (Chp-1), overgrowing with sphalerite (Sph) fridge in the outer subzone. Photo: $a-8-$ polished sample, $2-e-$ reflected light, $\partial-$ etched in $\mathrm{HNO}_{3}+\mathrm{HCl}$ 
Характерной особенностью гидротермального халькопирита (Chp-1) является разнообразие форм и размеров его кристаллов в трубах различного минерального состава. В пирит-халькопиритовых и сфалерит-пирит-халькопиритовых палеокурильщиках кристаллы халькопирита в плоскости аншлифа имеют угловатую, прямоугольную, треугольную, чечевицеобразную, копьевидную форму, часто с неровными зазубренными краями (рис. 3, a). Зачастую зерна халькопирита инкрустируются зернами пирита, в сфалерит-пирит-халькопиритовых трубах могут обрастать эпитаксиальными каймами и почками сфалерита (рис. 3, б, в). В некоторых трубах встречаются ритмично-зональные агрегаты с чередованием слоев халькопирита и сфалерита. Для халькопирит-пиритсфалеритовых труб свойственна небольшая мощность халькопиритовой зоны (менее 1 мм) и тесные графические срастания со сфалеритом (рис. 3, 2).
Точечные ЛА-ИСП-МС анализы выявили ряд геохимических отличий между гидротермальным халькопиритом труб различного минерального состава (табл. 1). В целом для халькопирита палеокурильщиков характерны широкие вариации концентраций некоторых элементов $\mathrm{V}(0,01-54,6$ г/T), Co $(0,001-41,3$ г/T), Zn (84,3-23087 г/T), Mo (0,001-21,1 г//), Ag (0,3-302 г/T), $\mathrm{Te}(0,01-186$ г/T), Ba (0,001-83,9 г/T), Pb (0,1-1892 г/T) и $\mathrm{Bi}(0,001-57,2$ г/т). Заметно, что вариации содержаний ряда элементов ( $\mathrm{V}, \mathrm{Co}, \mathrm{Se}, \mathrm{Mo}, \mathrm{Te}, \mathrm{Ba}, \mathrm{Bi})$ в халькопирите пирит-халькопиритовых (chp-lbs) и сфалерит-пирит-халькопиритовых (chp-lgs) труб выше, чем в халькопирите халькопирит-пирит-сфалеритовых (chp-1ws) палеокурильщиков. Значительные вариации концентраций $\mathrm{Ag}(5,9-302$ г/т) и Te $(0,37-186$ г/т) заметны для халькопирита сфалерит-пиритхалькопиритовых труб (chp-1ws).
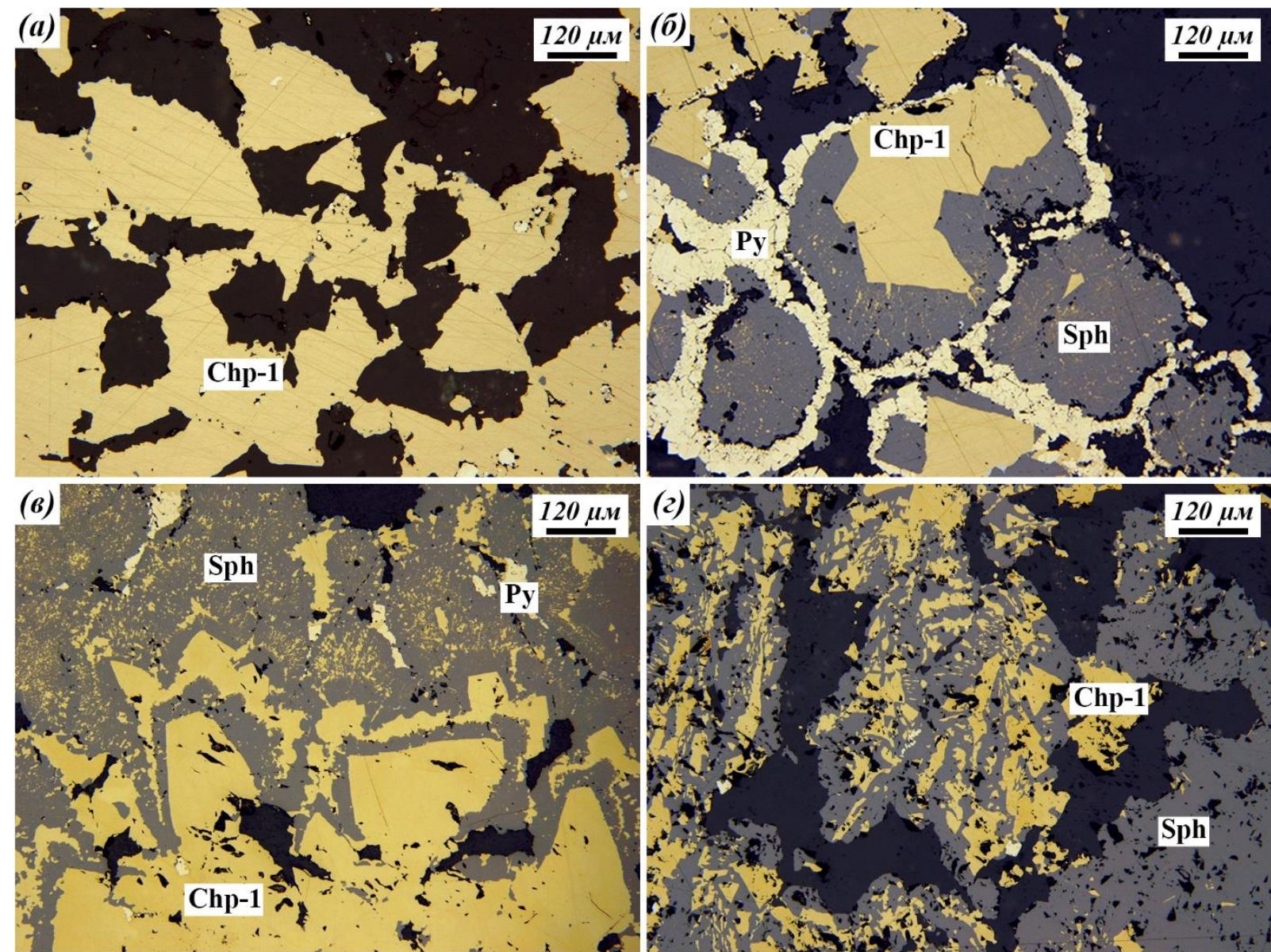

Рис. 3. Гидротермальный халькопирит (Chp-1) палеокурильщиков: а) угловатые кристаллы халькопирита, выполняюшие осевой канал пирит-халькопиритовой трубы; б) последовательное обрастание кристаллов халькопирита слоями гидротермального сфалерита (Sph) и пирита (Py); в) зональный сульфидный агрегат с изиклическим чередованием эпитакисальных слоев халькопирита и сфалерита; г) графические срастания сфалерита и халькопирита в осевом канале халькопирит-пирит-сфалеритовой трубы. Отраженный свет

Fig. 3. Hydrothermal chalcopyrite (Chp-1) palesmokers: a) angular crystals of chalcopyrite (Chp-1) in axial channel of chalcopyrite-pyrite chimneys; б) sequential overgrowing of chalcopyrite crystals with layers of hydrothermal sphalerite (Sph) and pyrite (Py); в) zonal sulfide aggregates with cyclic sequence of layers of chalcopyrite (Chp-1) and sphalerite (Sph); 2) graphic intergrowth of sphalerite (Sph) and chalcopyrite (Chp-1) in the axial channel of the sphalerite-pyrite-chalcopyrite chimney. Reflected light 
Таблица 1. Химический состав (2/m) гидротермального халькопирита пирит-халькопиритовых (chp-1bs), cфалеритпирит-халькопиритовых (chp-lgs) и халькопирит-пирит-сфалеритовых (chp-lws) труб палеокурильщиков

Table 1. Chemical composition $(\mathrm{g} / \mathrm{t})$ of hydrothermal chalcopyrite chalcopyrite-pyrite (chp-1bs), chalcopyrite-pyritesphalerite (chp-1gs) and sphalerite-pyrite-chalcopyrite (chp-1ws) chimneys of paleosmokers according to LAICP-MS

\begin{tabular}{|c|c|c|c|c|c|c|c|c|c|c|}
\hline $\begin{array}{c}\text { Параметры } \\
\text { Parameter }\end{array}$ & $\begin{array}{c}\text { Tрубы } \\
\text { Chimneys }\end{array}$ & V & $\mathrm{Mn}$ & Co & $\mathrm{Ni}$ & $\mathrm{Zn}$ & As & $\mathrm{Se}$ & Mo & $\mathrm{Ag}$ \\
\hline \multirow{3}{*}{$\begin{array}{l}\text { среднее } \\
\text { average }\end{array}$} & chp-1bs & 2,9 & 1,6 & 1,6 & 0,34 & 683 & 3,7 & 369 & 5,8 & 14,2 \\
\hline & chp-1gs & 1,7 & 4,6 & 0,01 & 0,10 & 250 & 2,9 & 97,2 & 4,9 & 66,8 \\
\hline & chp-1ws & 0,08 & 3,3 & 0,04 & 0,12 & 438 & 3,0 & 19,9 & 0,8 & 14,0 \\
\hline \multirow{3}{*}{$\delta$} & chp-1bs & 9,9 & 3,5 & 6,7 & 1,1 & 3271 & 8,7 & 241 & 21,1 & 15,0 \\
\hline & chp-1gs & 8,1 & 13,4 & 0,01 & 0,24 & 158 & 2,8 & 59,4 & 18,5 & 77,6 \\
\hline & chp-1ws & 0,14 & 15,4 & 0,04 & 0,34 & 489 & 9,7 & 7,7 & 2,4 & 10,8 \\
\hline \multirow{3}{*}{$\begin{array}{l}\text { макс } \\
\max \end{array}$} & chp-1bs & 54,6 & 15,4 & 41,3 & 6,8 & 23087 & 58,2 & 961 & 134 & 68,4 \\
\hline & chp-1gs & 45,4 & 65,0 & 0,04 & 0,96 & 799 & 12,1 & 265 & 101 & 302 \\
\hline & chp-1ws & 0,54 & 81,7 & 0,19 & 1,67 & 1970 & 47,7 & 37,6 & 11,6 & 53,9 \\
\hline \multirow{3}{*}{$\begin{array}{l}\text { мин } \\
\text { min }\end{array}$} & chp-1bs & 0,01 & 0,02 & 0,001 & 0,01 & 84,3 & 0,11 & 33,6 & 0,001 & 0,27 \\
\hline & chp-1gs & 0,01 & 0,03 & 0,001 & 0,001 & 131 & 0,1 & 25,4 & 0,001 & 5,9 \\
\hline & chp-1ws & 0,03 & 0,35 & 0,03 & 0,01 & 248 & 0,10 & 17,9 & 0,16 & 12,0 \\
\hline \multirow{3}{*}{$\begin{array}{l}\text { медиана } \\
\text { md }\end{array}$} & chp-1bs & 0,13 & 0,27 & 0,02 & 0,05 & 191 & 1,8 & 290 & 0,11 & 8,4 \\
\hline & chp-1gs & 0,07 & 0,14 & 0,01 & 0,001 & 210 & 2,4 & 80,3 & 0,21 & 33,5 \\
\hline & chp-1ws & 0,03 & 0,35 & 0,03 & 0,01 & 248 & 0,10 & 17,9 & 0,16 & 12,0 \\
\hline & & $\mathrm{Cd}$ & $\mathrm{Sn}$ & $\mathrm{Sb}$ & $\mathrm{Te}$ & $\mathrm{Ba}$ & $\mathrm{Au}$ & $\mathrm{Tl}$ & $\mathrm{Pb}$ & $\mathrm{Bi}$ \\
\hline \multirow{3}{*}{$\begin{array}{l}\text { среднее } \\
\text { average }\end{array}$} & chp-1bs & 6,7 & 12,2 & 5,3 & 10,6 & 3,7 & 0,28 & 0,14 & 16,3 & 4,3 \\
\hline & chp-1gs & 1,7 & 25,9 & 3,5 & 25,1 & 0,08 & 0,45 & 0,04 & 80,7 & 1,3 \\
\hline & chp-1ws & 5,1 & 22,0 & 2,0 & 0,60 & 0,08 & 0,25 & 0,02 & 20,6 & 0,05 \\
\hline \multirow{3}{*}{$\delta$} & chp-1bs & 15,3 & 5,0 & 5,5 & 22,1 & 14,6 & 0,28 & 0,24 & 11,7 & 8,7 \\
\hline & chp-1gs & 1,2 & 7,6 & 3,4 & 52,8 & 0,15 & 0,38 & 0,06 & 336 & 2,2 \\
\hline & chp-1ws & 4,5 & 6,5 & 2,1 & 0,51 & 0,20 & 0,15 & 0,06 & 20,5 & 0,12 \\
\hline \multirow{3}{*}{$\begin{array}{l}\text { макс } \\
\max \end{array}$} & chp-1bs & 108 & 19,9 & 24,0 & 154 & 83,9 & 1,4 & 1,4 & 46,9 & 57,2 \\
\hline & chp-1gs & 5,7 & 49,6 & 15,9 & 186 & 0,68 & 1,6 & 0,29 & 1892 & 9,6 \\
\hline & chp-1ws & 22,7 & 33,1 & 8,9 & 1,82 & 1,1 & 0,58 & 0,29 & 104 & 0,62 \\
\hline \multirow{3}{*}{$\begin{array}{l}\text { мин } \\
\text { min }\end{array}$} & chp-1bs & 0,47 & 4,5 & 0,06 & 0,55 & 0,01 & 0,01 & 0,001 & 0,13 & 0,03 \\
\hline & chp-1gs & 0,34 & 14,5 & 0,5 & 0,37 & 0,001 & 0,02 & 0,001 & 3,1 & 0,001 \\
\hline & chp-1ws & 0,97 & 11,2 & 0,18 & 0,01 & 0,01 & 0,04 & 0,001 & 2,10 & 0,001 \\
\hline \multirow{3}{*}{$\begin{array}{l}\text { медиана } \\
\text { md }\end{array}$} & chp-1bs & 4,6 & 10,4 & 2,7 & 4,7 & 0,08 & 0,20 & 0,03 & 14,9 & 0,90 \\
\hline & chp-1gs & 1,3 & 24,7 & 1,8 & 2,4 & 0,02 & 0,40 & 0,01 & 12,0 & 0,49 \\
\hline & chp-1ws & 3,5 & 22,5 & 1,4 & 0,53 & 0,02 & 0,24 & 0,001 & 14,4 & 0,02 \\
\hline
\end{tabular}

Примечание: количество проб для chp-1bs $N=49$, для chp-lgs $N=31$, для chp-1ws $N=28$. Приведены средние, максимальные, минимальные и медианные содержания $(2 / \mathrm{m})$. $\delta$-стандартное отклонение.

Note. Number of analyses for chp-1bs $N=49$, for chp-1gs $N=31$, for chp-1ws $N=28$. Average - average, max - maximum and min-minimum contents $(\mathrm{g} / \mathrm{t}) . \delta$-standard deviation, $m d-$ median value.

\section{Халькопирит сульфидных турбидитов}

Фланги Второй рудной залежи сложены чередованием алевропесчаных сульфидных турбидитов пиритхалькопиритового и халькопирит-пиритового состава с прослоями хлорит-кремнистых и кремнистых алевропелитов, вулканомиктовых песчаников и гравелитов (рис. 4, a).

Сульфидные слои в турбидитах мощностью до 1-1,5 см нередко характеризуются прогрессивной сортировкой сульфидного материала и наличием мелких (до 0,3-0,4 см) обломков хлоритизированных гиалокластов (рис. 4, a). В некоторых слоях сульфидных турбидитов сохраняются фрагменты пиритовых, пирит-халькопиритовых и сфалерит-халькопиритпиритовых руд, однако значительная часть первичных рудокластов замещена псевдоморфным халькопиритом (Chp-2). Сульфидные обломки, кристаллы и агрегаты позднего пирита сцементированы мелкозер- нистым халькопиритом (Chp-3). В прослоях хлориткремнистых слоев встречаются округлые и сглаженно-угловатые конкреции халькопирита (Chp-3nod). B некоторых слоях встречаются прожилки позднего халькопирита (Chp-4), подчеркивающие косое, почти согласное, направление микротрещин кливажа.

Псевдоморфный, тонкозернистый халькопирит (Chp-2) замещает рудокласты колломорфного и кристаллически-зернистого пирита (рис. 4, б). В агрегатах псевдоморфного халькопирита отмечены включения самородного золота и теллуридов (колорадоит, гессит, теллуровисмутит). По результатам ЛА-ИСП-МС анализов в псевдоморфном халькопирите заметны широкие вариации концентраций $\mathrm{Mn}(0,42-750$ г/T), Co (0,001-96,3 г/т), Mo (0,01-171 г/т), Sb (0,09-74,5 г/т), Te (4,0-244 г/т), Вa (0,01-14,6 г/т), Pb (0,6-565 г/т) и Bi (0,53-118 г/т) (табл. 2). Высокие медианные содержания Mn, Co, Ni, Mo, Sb, Te, Ba, Au, Tl, Pb и Bi 
отличают данный халькопирит от гидротермальных и других постседиментационных аналогов (табл. 2).

Цементационный, мелкозернистый халькопирит (Chp-3) цементирует сульфидные рудокласты и одиночные кристаллы пирита, образует прожилки и выполняет интерстиции в пиритовых агрегатах (рис. 4, в). Цементационный халькопирит относительно равномерно распределен внутри сульфидных турбидитов, однако в некоторых слоях количество халькопирита возрастает к кровле слоев. С прожилками данной разновидности халькопирита ассоциируют включения галенита, самородного золота, колорадоита, гессита, теллуровисмутитраклиджита, волынскита, петцита и алтаита [25]. По медианным содержаниям ряда элементов (Ti, $\mathrm{Zn}, \mathrm{Cd}, \mathrm{Se}$, $\mathrm{Ag}, \mathrm{Sn})$ цементационный халькопирит близок к псевдоморфной разновидности, а содержания других элементов-примесей на порядок ниже (табл. 2).

Конкреционный халькопирит (Chp-3nod) встречается в слоях хлорит-кремнистых алевропелитов, переслаивающихся с пирит-халькопиритовыми турбидитами (рис. 4, г). Конкреции халькопирита размером 0,1-0,2 мм имеют округлую, реже угловатую, форму с неровными, зазубренными краями. Травление халькопирита с помощью раствора «царской водки» выявило крупнозернистое строение конкреций с размерами зерен до 0,1-0,15 мм. Конкреции обычно сложены срастанием 2-3 кристаллов халькопирита, иногда проявляющим сдвойникованное строение. В объеме конкреции халькопирита имеют шаровидную и эллипсоидальную морфологию, усложненную многочисленными мелкими гранями, ступенями, буграми и ямками. В халькопирите конкреций отмечаются включения сфалерита, пирита, кварца, хлорита, а также тесные срастания самородного золота $\mathrm{Au}_{(0,48-0,79)} \mathrm{Ag}_{(0,2-0,52)} \mathrm{Hg}_{(0-0,02)}$, петцита, гессита, колорадоита, селенсодержащих алтаита (Se до 1,9 мас. \%) и галенита ( $\mathrm{Se}$ до 2,1 мас. \%), пластинок волынскита и минералов серии теллуровисмутитраклиджит (Pb до 15,4 мас. \%). Включения редких минералов тяготеют к центральной части конкреций, где ассоциируют с включениями сфалерита. В краевых частях конкреций нередко можно заметить частичное замещение халькопирита и теллуридов хлоритом.

Проведенное микрогеохимическое картирование конкреций методом ЛА-ИСП-МС не выявило зонального распределения химических элементов и подтвердило их относительно гомогенное строение. Точечный ЛА-ИСП-МС анализ выявил в халькопирите конкреций сильные вариации содержаний ряда элементов-примесей (табл. 2): $\mathrm{Au}(0,002-5200$ г/T), Ag (0,06-22000 г/T), Te $(0,09-12800$ г/T), Bi (0,03-2480 г/T), Pb (0,04-449 г/T), Zn (104-69716 г/т) и Cd (0,4-377 г/т). Аномально высокие средние содержания ряда элементов (Zn, Ag, Te, $\mathrm{Au}, \mathrm{Pb}, \mathrm{Bi})$ вызваны ураганными концентрациями в некоторых анализах. По медианным содержаниям Mn, $\mathrm{As}, \mathrm{Co}, \mathrm{Ni}, \mathrm{Mo}, \mathrm{Au}, \mathrm{Ag}, \mathrm{Sn}, \mathrm{Sb}$ и Те халькопирит конкреций наиболее близок к цементационному халькопириту сульфидных турбидитов.

Прожилковыци, крупнозернистый халькопирит (Chp-4) образует в слоях сульфидных турбидитов субсогласные со слоистостью прожилки и мелкие гнезда (рис. 4,2 ). В зернах прожилкового халькопирита после травления в растворе $\mathrm{HNO}_{3}+\mathrm{HCl}$ выявляются полисинтетические двойники [25]. Для прожилкового халькопирита не характерны включения самородного золота и теллуридов и свойственны пониженные концентрации химических элементов относительно прочих разновидностей халькопирита. Медианные содержания большинства элементов-примесей в прожилковом халькопирите ниже, чем в других новообразованных разновидностях халькопирита (табл. 2). В сравнении с гидротермальными аналогами прожилковый халькопирит наиболее близок к халькопирит-пиритсфалеритовым палеокурильщикам, но при этом обеднен примесями Мo (0,01-0,85 г/т), Au (0,03-0,14 г/т), $\operatorname{Ag}(0,61-2,7$ г/Т) и $\operatorname{Sn}(2,7-3,4$ г/Т).

Сравнительный анализ распределения элементовпримесей в халькопирите

На диаграммах «box\&whiskers» (рис. 5) отражена статистическая информация по содержаниям элементов-примесей в гидротермальных и постседиментационных разновидностях халькопирита руд Юбилейного месторождения.

$\mathrm{Mn}, \mathrm{Co}, \mathrm{Ni}, \mathrm{As}$ u $\mathrm{Tl}$. Гидротермальный халькопирит отличается от постседиментационных разновидностей относительно невысокими содержаниями $\mathrm{Mn}, \mathrm{Co}$, $\mathrm{Ni}, \mathrm{As}$ и $\mathrm{Tl}$ (рис. $5, a-2, e$ ). По положению медианных значений заметно некоторое снижение содержаний Co и As в ряду постседиментационных разновидностей халькопирита и понижение концентраций $\mathrm{Tl}$ в ряду гидротермального халькопирита от пиритхалькопиритовых к существенно сфалеритовым трубам. Значительная часть анализов конкреций по содержаниям $\mathrm{Mn}, \mathrm{Co}, \mathrm{Ni}, \mathrm{As}$ и Tl попадает в область значений цементационного халькопирита и превосходит обедненный элементами-примесями халькопирит прожилков.

$S b$. В рядах как гидротермальных труб (от пиритхалькопиритовых к существенно сфалеритовым трубам), так и постседиментационных разновидностей халькопирита наблюдается снижение медианных содержаний $\mathrm{Sb}$ (рис. 5, д). Исключением выступает халькопирит прожилков, концентрации $\mathrm{Sb}$ в котором выше, чем в конкрециях. Единичные аномально высокие значения Sb наблюдаются для всех разновидностей халькопирита.

Mo. Как для гидротермальных, так и для постседиментационных разновидностей халькопирита характерны близкие содержания Мо (рис. 5, ж). Концентрации Мо отличаются в конкрециях халькопирита различных слоев. Высокие значения Мо в одном из слоев $(0,1-11,5$ г/т) выглядят как аномальные выбросы на выборке относительно другого слоя с низкими содержаниями $(0,01-0,08$ г/т).

$S n$. Элементом, разграничивающим постседиментационные и гидротермальные разновидности халькопирита, выступает Sn (рис. 5, 3). Характерной чертой постседиментационного халькопирита является в несколько раз меньшие содержания олова по сравнению с гидротермальным халькопиритом. Медианные содержания $\mathrm{Sn}$ в конкреционном халькопирите, тем не менее, несколько превосходят халькопирит сульфидных турбидитов. 

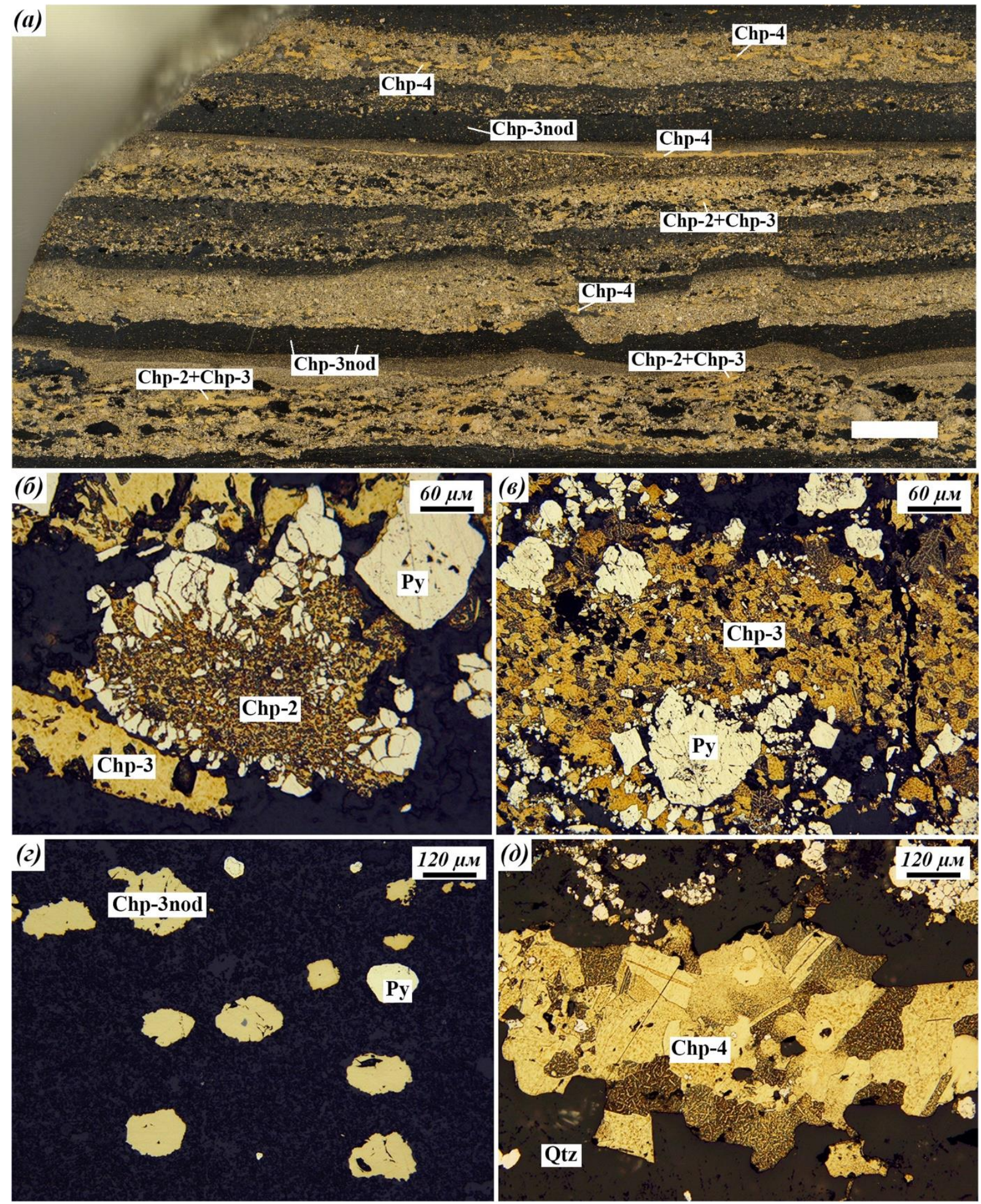

Рис. 4. Халькопирит сульфидных турбидитов: а) пирит-халькопиритовый турбидит с агрегатами псевдоморфного и иементационного халькопирита (Chp-2+Chp-3), конкрециями (Chp-3nod), а также халькопиритовыми прожилками (Chp-4); б) псевдоморфоза халькопирита-2 (Chp-2) по агрегату пирита (Ру) в срастании с иементационным халькопиритом-3 (Chp-3); в) агрегат цементационного халькопирита-3 (Chp-3); г) округлье и сглаженно-угловатые конкреции халькопирита (Chp-3nod) в ассочиации с кристаллами пирита (Pу); д) прожилок халькопирита-4 (Chp-4) в срастании с кварием (Qtz). Фото: а) полированньй образеи, б-г) отраженный свет, б-г) протравлено в $\mathrm{HNO}_{3}+\mathrm{HCl}$

Fig. 4. Chalcopyrite of sulfide turbidites: a) chalcopyrite-pyrite turbidite with pseudomorphic and cementation chalcopyrite (Chp-2+Chp-3), nodules (Chp-3nod), and chalcopyrite veins (Chp-4); б) aggregate of chalcopyrite-2 (Chp-2) after pyrite aggregate (Py) with cementation chalcopyrite-3 (Chp-3); в) aggregate of cementation chalcopyrite-3 (Chp-3); 2) rounded and angular nodules of chalcopyrite (Chp-3nod) with pyrite crystals (Py); d) veins of chalcopyrite-4 (Chp-4) with quartz (Qtz). Photo: a) polished sample, 6-2) reflected light, 6-2) etched in $\mathrm{HNO}_{3}+\mathrm{HCl}$ 
Таблица 2. Химический состав (2/m) псевдоморфного (chp-2), цементационного (chp-3), конкреционного (chp-3nоd) и прожсилкового (chp-4) халькопирита сульфидных турбидитов и хлорит-кремнистых пород

Table 2. Chemical composition ( $g / t$ ) of pseudomorphic (chp-2), interstitial (chp-3), nodule (chp-3nod) and veinlet (chp-4) chalcopyrite of sulfide turbidites and chlorite-siliceous rocks according to LA-ICP-MS

\begin{tabular}{|c|c|c|c|c|c|c|c|c|c|c|c|}
\hline $\begin{array}{c}\text { Параметры } \\
\text { Parameter }\end{array}$ & $\begin{array}{c}\text { Тип } \\
\text { Type } \\
\end{array}$ & $\mathrm{Ti}$ & V & $\mathrm{Cr}$ & $\mathrm{Mn}$ & Co & $\mathrm{Ni}$ & $\mathrm{Zn}$ & As & $\mathrm{Se}$ & Mo \\
\hline \multirow{4}{*}{$\begin{array}{l}\text { среднее } \\
\text { average }\end{array}$} & chp-2 & 8,3 & 4,9 & 0,85 & 156 & 16,1 & 4,3 & 197,6 & 132 & 192 & 25,4 \\
\hline & chp-3 & 6,1 & 3,4 & 0,68 & 63,4 & 12,6 & 6,3 & 1178 & 69,5 & 212 & 10,5 \\
\hline & chp-3nod & 1,95 & 1,1 & 1,1 & 8,4 & 1,4 & 0,5 & 2889 & 7,2 & 184 & 0,5 \\
\hline & chp-4 & 0,68 & 0,11 & 0,85 & 0,32 & 0,03 & 0,04 & 185 & 0,77 & 159 & 0,11 \\
\hline \multirow{4}{*}{$\delta$} & chp-2 & 7,1 & 5,9 & 0,67 & 172 & 22,3 & 5,14 & 166 & 165 & 44,5 & 39,3 \\
\hline & chp-3 & 5,1 & 11,5 & 0,82 & 180 & 24,5 & 15,9 & 6552 & 129 & 92,3 & 28,0 \\
\hline & chp-3nod & 5,24 & 3,0 & 1,1 & 28,5 & 6,7 & 1,5 & 11010 & 30,7 & 77,8 & 1,9 \\
\hline & chp-4 & 0,61 & 0,19 & 0,78 & 0,51 & 0,02 & 0,03 & 73,4 & 0,73 & 38,6 & 0,27 \\
\hline \multirow{4}{*}{$\begin{array}{l}\text { макс } \\
\max \end{array}$} & chp-2 & 34,8 & 27,0 & 2,2 & 750 & 96,3 & 16,9 & 791 & 621 & 284 & 171 \\
\hline & chp-3 & 23,2 & 79,1 & 3,2 & 970 & 116 & 99,6 & 46978 & 508 & 637 & 123 \\
\hline & chp-3nod & 34,1 & 17,1 & 4,1 & 180 & 42,3 & 8,8 & 69715 & 195 & 408 & 11 \\
\hline & chp-4 & 1,5 & 0,57 & 1,9 & 1,6 & 0,07 & 0,12 & 379 & 1,9 & 242 & 0,85 \\
\hline \multirow{4}{*}{$\begin{array}{l}\text { мин } \\
\text { min }\end{array}$} & chp-2 & 0,54 & 0,01 & 0,05 & 0,42 & 0,001 & 0,02 & 61,5 & 0,20 & 64,0 & 0,01 \\
\hline & chp-3 & 0,04 & 0,01 & 0,01 & 0,04 & 0,001 & 0,01 & 62,3 & 0,07 & 91,0 & 0,01 \\
\hline & chp-3nod & 0,15 & 0,02 & 0,001 & 0,001 & 0,001 & 0,005 & 104 & 0,05 & 68 & 0,01 \\
\hline & chp-4 & 0,04 & 0,001 & 0,15 & 0,02 & 0,01 & 0,02 & 147 & 0,02 & 104 & 0,01 \\
\hline \multirow{4}{*}{$\begin{array}{l}\text { медиана } \\
\text { md }\end{array}$} & chp-2 & 7,0 & 3,1 & 0,63 & 83,1 & 6,0 & 2,1 & 116 & 70 & 193 & 6,0 \\
\hline & chp-3 & 6,2 & 0,22 & 0,32 & 1,4 & 0,37 & 0,13 & 115 & 2,8 & 193 & 0,03 \\
\hline & chp-3nod & 1,0 & 0,14 & 0,8 & 1,2 & 0,04 & 0,17 & 198 & 1,5 & 171 & 0,01 \\
\hline & chp-4 & 0,78 & 0,01 & 0,39 & 0,12 & 0,02 & 0,02 & 164 & 0,90 & 156 & 0,02 \\
\hline & & $\mathrm{Ag}$ & $\mathrm{Cd}$ & Sn & $\mathrm{Sb}$ & $\mathrm{Te}$ & $\mathrm{Ba}$ & $\mathrm{Au}$ & $\mathrm{Tl}$ & $\mathrm{Pb}$ & $\mathrm{Bi}$ \\
\hline \multirow{4}{*}{$\begin{array}{l}\text { среднее } \\
\text { average }\end{array}$} & chp-2 & 12,6 & 2,2 & 4,2 & 21,1 & 44,6 & 1,8 & 1,5 & 2,5 & 184 & 47,7 \\
\hline & chp-3 & 31,4 & 8,7 & 4,0 & 6,5 & 247 & 0,32 & 0,86 & 0,91 & 60,4 & 247 \\
\hline & chp-3nod & 2058 & 22,6 & 4,5 & 3,3 & 1349 & 0,25 & 266,7 & 0,1 & 52,8 & 88,3 \\
\hline & chp-4 & 1,4 & 1,3 & 3,1 & 2,1 & 3,8 & 0,04 & 0,07 & 0,01 & 8,8 & 3,4 \\
\hline \multirow{4}{*}{$\delta$} & chp-2 & 10,4 & 1,6 & 0,93 & 18,1 & 51,1 & 3,4 & 1,2 & 2,9 & 145 & 32,4 \\
\hline & chp-3 & 152 & 46,5 & 0,73 & 7,7 & 1577 & 0,67 & 1,3 & 2,5 & 77,2 & 1638 \\
\hline & chp-3nod & 5354 & 62,8 & 1,0 & 8,1 & 3333 & 0,46 & 920,7 & 0,4 & 109,1 & 401,7 \\
\hline & chp-4 & 0,6 & 0,87 & 0,23 & 0,63 & 3,23 & 0,02 & 0,03 & 0,01 & 3,9 & 2,7 \\
\hline \multirow{4}{*}{$\begin{array}{l}\text { макс } \\
\max \end{array}$} & chp-2 & 41,6 & 5,5 & 7,6 & 74,5 & 244 & 14,6 & 3,9 & 9,8 & 565 & 118 \\
\hline & chp-3 & 1078 & 334 & 7,6 & 33,5 & 11279 & 3,08 & 5,4 & 13,7 & 337 & 11712 \\
\hline & chp-3nod & 22000 & 377 & 7,9 & 38,2 & 12850 & 2,68 & 5200 & 2,6 & 449 & 2480 \\
\hline & chp-4 & 2,7 & 2,9 & 3,4 & 3,4 & 11,5 & 0,08 & 0,14 & 0,02 & 18,0 & 103 \\
\hline \multirow{4}{*}{$\begin{array}{l}\text { мин } \\
\text { min }\end{array}$} & chp-2 & 1,3 & 0,09 & 2,5 & 0,09 & 4,0 & 0,01 & 0,04 & 0,001 & 0,56 & 0,53 \\
\hline & chp-3 & 0,08 & 0,01 & 2,8 & 0,08 & 0,96 & 0,01 & 0,01 & 0,001 & 0,15 & 0,08 \\
\hline & chp-3nod & 0,06 & 0,37 & 2,9 & 0,01 & 0,09 & 0,001 & 0,002 & 0,002 & 0,04 & 0,03 \\
\hline & chp-4 & 0,61 & 0,37 & 2,7 & 1,2 & 0,62 & 0,02 & 0,03 & 0,001 & 4,1 & 1,2 \\
\hline \multirow{4}{*}{$\begin{array}{l}\text { медиана } \\
\text { md }\end{array}$} & & 9,5 & 1,7 & 4,0 & 18,5 & 27,2 & 0,73 & 1,1 & 1,1 & 174 & 42,8 \\
\hline & chp-3 & 2,6 & 0,83 & 3,9 & 4,3 & 9,20 & 0,02 & 0,29 & 0,02 & 31,7 & 9,9 \\
\hline & chp-3nod & 2,5 & 5,1 & 4,6 & 0,34 & 5,3 & 0,02 & 0,25 & 0,019 & 2,42 & 0,8 \\
\hline & chp-4 & 1,3 & 0,96 & 3,1 & 1,9 & 3,26 & 0,04 & 0,07 & 0,001 & 8,1 & 2,8 \\
\hline
\end{tabular}

Примечание: количество проб для chp-2 N=23, для chp-3 $N=51$, для chp-3nod N=41, для chp-4 N=9. Приведень средние, максимальные, минимальные и медианные содержания (2/m). $\delta$-стандартное отклонение.

Note. Number of analyses for chp-2 $N=23$, for chp-3 $N=51$, for chp-3nod $N=41$, for chp-4 N=9. Average - average, max maximum and min - minimum contents $(\mathrm{g} / \mathrm{t})$. $\delta$-standard deviation, $\mathrm{md}$ - median value.

$\mathrm{Se}$. Содержания $\mathrm{Se}$ слабо варьируют в постседиментационных разновидностях халькопирита (рис. $5, u$ ). Напротив, контрастная картина распределения примеси Se наблюдается в гидротермальном халькопирите труб различного состава. По содержаниям Se постседиментационный халькопирит занимает промежуточное положение между пирит-халькопиритовыми и сфалерит-пирит-халькопиритовыми разновидностями труб.

$A u, A g$. Несмотря на существенные отличия в средних содержаниях примесей $\mathrm{Au}$ и $\mathrm{Ag}$ в разновидностях халькопирита, медианные значения варьируют в них незначительно (рис. $5, \kappa, л$ ). На диаграммах за- метно некоторое понижение концентраций примесей $\mathrm{Au}$ и $\mathrm{Ag}$ в ряду от псевдоморфного к цементационным, конкреционным и прожилковым разновидностям халькопирита.

$T e$. На диаграмме концентраций Те (рис. 5, м) заметно снижение содержаний в рядах гидротермальных и постседиментационных разновидностей халькопирита. Наиболее контрастная картина наблюдается на примере халькопирита палеокурильщиков, где медианные содержания $\mathrm{Te}$ в халькопирит-пиритсфалеритовых трубах на порядок ниже, чем в пиритхалькопиритовых и сфалерит-пирит-халькопиритовых трубах. 
$P b$. Распределение содержаний $\mathrm{Pb}$ в халькопирите крайне неравномерное с единичными выбросами содержаний $\mathrm{Pb}$ выше квартиля 75 \% во всех разновидностях халькопирита (рис. 5, $\mu$ ). По медианным концентрациям $\mathrm{Pb}$ постседиментационные разновидно- сти халькопирита заметно различаются. В меньшей степени это свойственно для гидротермального халькопирита, в котором отмечаются довольно близкие медианные содержания свинца.
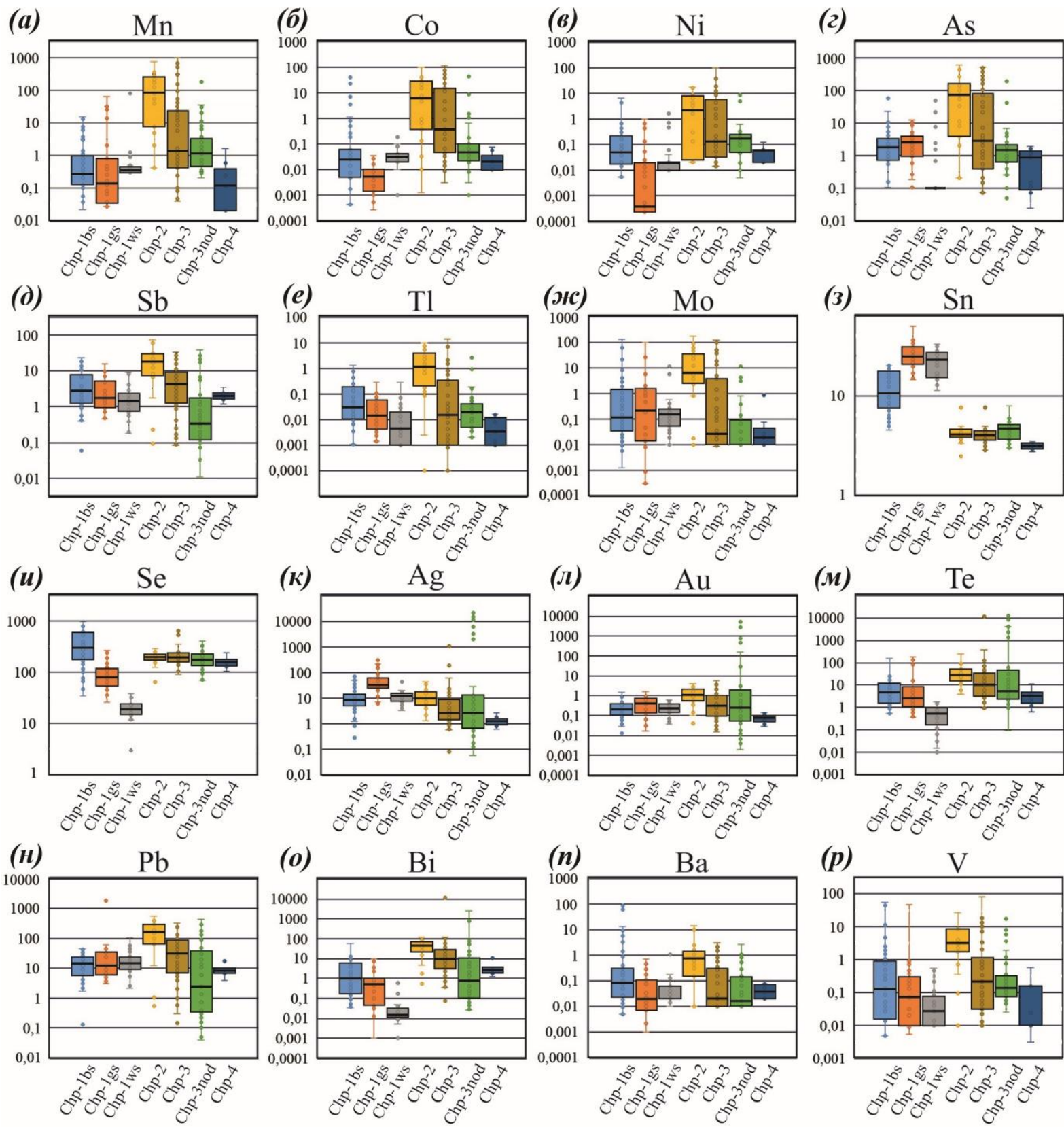

Рис. 5. Распределение элементов-примесей в разновидностях халькопирита Юбилейного месторождения. Окрашенные прямоугольники ограничены по вертикали 25 и 75 \% квантилями, горизонтальная линия в прямоугольниках - значения медианы. Вертикальные линии характеризуют минимальные и максимальные значения. Круглые точки за пределами вертикальных линий - аномальные выбросы. Ряд гидротермального халькопирита труб палеокурильщиков: Chp-lbs - пирит-халькопиритового $\rightarrow$ Chp-lgs - cфалерит-пиритхалькопиритового $\rightarrow$ Chp-lws - халькопирит-пирит-сфалеритового состава. Ряд постседиментационных разновидностей халькопирита: Chp-2 - псевдоморфный $\rightarrow$ Chp-3 - иементационный $\rightarrow$ Chp-3под - конкреиионный $\rightarrow C h p-4$ - прожилковый

Fig. 5. Distribution of chemical elements in various types of chalcopyrite. The colored rectangles limited by 25 and $75 \%$ quantiles, the horizontal line in rectangles - median value. Vertical lines mark minimum and maximum values. Round point - abnormal values. The range of hydrothermal chalcopyrite of paleosmokers: Chp-1bs - chalcopyritepyrite $\rightarrow$ Chp-1gs - chalcopyrite-pyrite-sphalerite $\rightarrow$ Chp-1ws - sphalerite-pyrite-chalcopyrite composition. The range of post-sedimentary chalcopyrite: Chp-2 - pseudomorphic $\rightarrow$ Chp-3 - interstitial $\rightarrow$ Chp-3nod - nodule $\rightarrow$ Chp-4 - veinlet 
Bi. Снижение медианных содержаний Ві отмечается в рядах гидротермальных и постседиментационных разновидностей халькопирита (рис. 5,o). Следует отметить, что Ві в новообразованном халькопирите сульфидных турбидитов несколько выше, чем в халькопирите сульфидных труб. В конкреционном халькопирите содержания Ві ниже, чем в цементационном, соответствующем халькопириту пирит-халькопиритовых труб.

$B a$. Содержания Ва низкие (до 2,7 г/т), и его распределение крайне неоднородное во всех разновидностях халькопирита (рис. $5, n$ ).

$V$. Медианные содержания ванадия снижаются в рядах как гидротермальных, так и постседиментационных разновидностей халькопирита (рис. $5, p$ ).

\section{Минерально-геохимические ассоциации халькопирита}

Методом максимального корреляционного пути [28] для каждого типа халькопирита были рассчитаны минералого-геохимические ассоциации (табл. 3). В ассоциациях химических элементов в изученных разновидностях халькопирита наблюдаются как отличия, так и общие для всех особенности. Так, например, присутствует устойчивая связь $\mathrm{As}+\mathrm{Co}$, в которую иногда входят $\mathrm{Ni}, \mathrm{Mn}, \mathrm{Bi}, \mathrm{Au}$ и Tl, отражающая присутствие включений пирита в халькопирите. Данная ассоциация отсутствует в прожилковом халькопирите (chp-4), в котором Со связан с Mo, а не с As. В группу, связанную с включениями сфалерита, помимо сильной связи $(\mathrm{Zn}+\mathrm{Cd})$ в некоторых случаях входят литогенные компоненты $(\mathrm{Cd}+\mathrm{Zn}+\mathrm{V}+\mathrm{Ti}$ в псевдоморфном) и элементы теллуридов висмута и серебpa $(\mathrm{Zn}+\mathrm{Cd}+\mathrm{Te}+\mathrm{Bi}+\mathrm{Ag}$ в цементационном). Для прожилкового халькопирита (chp-4) не характерна ассоциация $\mathrm{Zn}+\mathrm{Cd}$, по-видимому, благодаря незначительному количеству включений сфалерита. В гидротермальном халькопирите в сфалеритовую ассоцииацию $(\mathrm{Zn}+\mathrm{Cd}) \quad$ входят $\mathrm{Pb} \quad$ в сфалерит-пиритхалькопиритовых (chp-1gs) и $\mathrm{Tl}$ в халькопирит-пиритсфалеритовых (chp-1ws) палеокурильщиках.

Особый интерес представляет изменение связей элементов, связанных с включениями редких минералов в разновидностях халькопирита. В гидротермальном халькопирите только для пирит-халькопиритовых труб (chp-lbs) наблюдается устойчивая $(\mathrm{Au}+\mathrm{Te}+\mathrm{Bi}+\mathrm{Se})$ ассоциация, отражающая присутствие самородного золота и теллуридов висмута. $(\mathrm{Te}+\mathrm{Ag}+\mathrm{Se}+\mathrm{Sn})$ ассоциация элементов выявлена для халькопирита сфалерит-пирит-халькопиритовых (chplgs) труб, (Ag+Pb+Sb+Mo+Te+Se) ассоциация - для халькопирит-пирит-сфалеритовых (chp-1ws) труб и связана с включениями гессита, галенита и, вероятно, минералов блеклых руд. Для цементационного халькопирита (chp-3) сульфидных турбидитов характерна связь теллуридов с включениями сфалерита $(\mathrm{Zn}+\mathrm{Cd}+\mathrm{Te}+\mathrm{Bi}+\mathrm{Ag})$, а в псевдоморфном халькопирите (chp-2) заметны ассоциации самородного золота с пиритом (As+Co+Ni+Tl+Au), Bi c Ag и сложно интерпретируемая ассоциация Те с Ва. Особые ассоциации характерны для прожилкового халькопирита (chp-4), в котором связи, характерные для других разновидностей халькопирита, нарушаются и присут- ствуют такие сложно интерпретируемые группы, как $\mathrm{Au}+\mathrm{Ba}, \mathrm{Se}+\mathrm{Mn}+\mathrm{V}$ и $\mathrm{Co}+\mathrm{Mo}$.

В халькопирите конкреций (chp-3nod) установлены несколько ассоциаций элементов, отличающиеся от наблюдаемых в группе других разновидностей постседиментационного халькопирита. Здесь геохимическая (As+Co+Mn+Tl) ассоциация (табл. 3) связана с элементами изоморфно входящих в состав включений пирита. Вторая $\mathrm{Sb}+\mathrm{Zn}+\mathrm{Cd}$ ассоциация объединяет элементы-примеси, характерные для сфалерита. Tретья $\mathrm{Pb}+\mathrm{Bi}+\mathrm{Se}$ группа элементов отражает присутствие включений селенсодержащего галенита и, вероятно, алтаита. Четвертая $\mathrm{Te}+\mathrm{Ag}+\mathrm{Au}$ ассоциация объясняется присутствием срастаний теллуридов с самородным золотом. Часть элементов ( $\mathrm{Sn}, \mathrm{Mo}, \mathrm{Ba}, \mathrm{Ti}$ ) находятся в самом конце корреляционного ряда и имеют слабые незначимые связи с другими элементами. Общей для конкреционного и гидротермального халькопирита пирит-халькопиритовых труб (chp-1bs) выступает связь $\mathrm{Bi}+\mathrm{Se}$, которая отлична в прочих разновидностях халькопирита и объединяет Se с другими элементами, такими как $\mathrm{Sn}, \mathrm{Ag}, \mathrm{Te}, \mathrm{Mn}$ и V. Так же как и в других новообразованных и гидротермальных разновидностях халькопирита, в конкрециях отмечается устойчивая ассоциация химических элементов, связанная с включениями пирита (As+Co+Mn+Tl).

\section{Обсуждение результатов}

Выделенные разновидности халькопирита в рудах Юбилейного месторождения значительно отличаются по текстурно-структурным и геохимическим характеристикам, что отражают разные стадии формирования колчеданных руд и специфические условия литогенеза сульфидных отложений.

Гидротермальный халькопирит сульфидных труб формировался в высокотемпературных (до 350$400{ }^{\circ} \mathrm{C}$ ) условиях, сопоставимых с температурами образования современных черных курильщиков [12 и ссылки внутри]. Моделям роста труб курильщиков посвящено значительное количество публикаций, где показано отложение халькопирита из концентрированных и высокотемпературных гидротермальных растворов [12, 29-32]. В трубах палеокурильщиков Юбилейного месторождения центростремительный рост кристаллов халькопиритовой стенки был сопряжен с обрастанием внешней и внутренней ее части колломорфным пиритом, сфалеритом, халькопиритом, марказитом, галенитом и блеклыми рудами. По мере увеличения в гидротермальных трубах относительного количества сфалерита наблюдается смена копьевидных крупнозернистых агрегатов халькопирита на графические и эпитаксиальные сростки халькопирита и сфалерита (рис. 3).

Высокочувствительным методом ЛА-ИСП-МС зафиксировано контрастное распределение элементов-примесей в гидротермальном халькопирите труб различного минерального состава. Медианные значения содержаний элементов высокотемпературной (Se, $\mathrm{Bi})$, среднетемпературной (Te, $\mathrm{Pb}, \mathrm{Sb})$ и низкотемпературной (Tl) ассоциаций в халькопирите понижаются в ряду от пирит-халькопиритовых к халькопирит- 
пирит-сфалеритовым палеокурильщикам. Некоторыми среднетемпературными элементами, такими как $\mathrm{Sn}$ и Ag, халькопирит сфалеритсодержащих труб, наоборот, обогащен в большей степени по сравнению с пирит-халькопиритовыми трубами. Подобные тренды на снижение концентраций некоторых элементовпримесей в сульфидах по мере увеличения количе- ства сфалерита отмечаются в гидротермальных трубах многих колчеданных залежей Урала [12]. Халькопирит труб Юбилейного месторождения по сравнению со своими аналогами на других колчеданных залежах Урала обладает сопоставимыми средними концентрациями большинства химических элементов [5].

Таблица 3. Ассоччиации химических элементов в гидротермальных и постседиментациионных разновидностях халькопирuma

Table 3. Chemical element assemblages in hydrothermal and post-sedimentation types of chalcopyrite

\begin{tabular}{|c|c|}
\hline Минерал/Mineral & Ассоциации/Association \\
\hline $\begin{array}{l}\text { Гидротермальный халькопирит } \\
\text { (chp-1bs) } \\
\text { Hydrothermal chalcopyrite (chp-1bs) }\end{array}$ & $\mathrm{I}(\mathrm{Ba}+\mathrm{V})+\mathrm{II}(\mathrm{Mo}+\mathrm{Tl}+\mathrm{Sb}+\mathrm{Pb})+\mathrm{III}(\mathrm{Zn}+\mathrm{Cd})-\mathrm{Mn}-\mathrm{IV}(\mathrm{Au}+\mathrm{Te}+\mathrm{Bi}+\mathrm{Se})-\mathrm{V}(\mathrm{Ni}+\mathrm{Co}+\mathrm{As})-\mathrm{VI}(\mathrm{Ag}+\mathrm{Sn})$ \\
\hline $\begin{array}{l}\text { Гидротермальный халькопирит } \\
\text { (chp-1gs) } \\
\text { Hydrothermal chalcopyrite (chp-1gs) }\end{array}$ & $\mathrm{I}(\mathrm{Te}+\mathrm{Ag}+\mathrm{Se}+\mathrm{Sn})-\mathrm{II}(\mathrm{Cd}+\mathrm{Zn}+\mathrm{Pb})-\mathrm{Au}-\mathrm{III}(\mathrm{Ni}+\mathrm{As})+\mathrm{IV}(\mathrm{Ba}+\mathrm{V})+\mathrm{Co}-\mathrm{V}(\mathrm{Tl}+\mathrm{Mo})+\mathrm{VI}(\mathrm{Bi}+\mathrm{Sb}+\mathrm{Mn})$ \\
\hline $\begin{array}{l}\text { Гидротермальный халькопирит } \\
\text { (chp-1ws) } \\
\text { Hydrothermal chalcopyrite (chp-1ws) }\end{array}$ & $\mathrm{I}(\mathrm{Bi}+\mathrm{Mn}+\mathrm{Ni}+\mathrm{Co}+\mathrm{As})+\mathrm{II}(\mathrm{Ag}+\mathrm{Pb}+\mathrm{Sb}+\mathrm{Mo}+\mathrm{Te}+\mathrm{Se})-\mathrm{Sn}-\mathrm{V}-\mathrm{Au}-\mathrm{III}(\mathrm{Zn}+\mathrm{Cd}+\mathrm{Tl})-\mathrm{Ba}$ \\
\hline $\begin{array}{l}\text { Псевдоморфный халькопирит (chp-2) } \\
\text { Pseudomorphic chalcopyrite (chp-2) }\end{array}$ & $\mathrm{I}(\mathrm{As}+\mathrm{Co}+\mathrm{Ni}+\mathrm{Tl}+\mathrm{Au})+\mathrm{II}(\mathrm{Pb}+\mathrm{Sb})+\mathrm{III}(\mathrm{Bi}+\mathrm{Ag})-\mathrm{Mn}-\mathrm{Sn}-\mathrm{Cr}-\mathrm{IV}(\mathrm{Cd}+\mathrm{Zn}+\mathrm{V}+\mathrm{Ti})-(\mathrm{Te}+\mathrm{Ba})-\mathrm{Mo}-\mathrm{Se}$ \\
\hline $\begin{array}{l}\text { Цементационный халькопирит (chp-3) } \\
\text { Instertitial chalcopyrite (chp-3) }\end{array}$ & $\mathrm{I}(\mathrm{Zn}+\mathrm{Cd}+\mathrm{Te}+\mathrm{Bi}+\mathrm{Ag})-\mathrm{II}(\mathrm{Au}+\mathrm{Pb}+\mathrm{Sb})+\mathrm{Mn}+\mathrm{Ba}+\mathrm{Sn}-\mathrm{III}(\mathrm{Ti}+\mathrm{V}+\mathrm{Cr})-\mathrm{IV}(\mathrm{As}+\mathrm{Co}+\mathrm{Ni})-\mathrm{V}(\mathrm{Tl}+\mathrm{Mo})-\mathrm{Se}$ \\
\hline $\begin{array}{l}\text { Халькопирит конкреций (chp-3nod) } \\
\text { Nodular chalcopyrite (chp-3nod) }\end{array}$ & $\mathrm{I}(\mathrm{As}+\mathrm{Co}+\mathrm{Mn}+\mathrm{Tl})+\mathrm{V}+\mathrm{II}(\mathrm{Sb}+\mathrm{Zn}+\mathrm{Cd})+\mathrm{III}(\mathrm{Pb}+\mathrm{Bi}+\mathrm{Se})+\mathrm{IV}(\mathrm{Te}+\mathrm{Ag}+\mathrm{Au})-\mathrm{Sn}-\mathrm{Mo}-\mathrm{Ba}-\mathrm{Ti}$ \\
\hline $\begin{array}{l}\text { Прожилковый халькопирит (chp-4) } \\
\text { Veinlet chalcopyrite (chp-4) }\end{array}$ & $\mathrm{I}(\mathrm{Bi}+\mathrm{Ag}+\mathrm{Sb})+\mathrm{II}(\mathrm{Te}+\mathrm{Pb})+\mathrm{Zn}-\mathrm{Ti}-\mathrm{II}(\mathrm{Co}+\mathrm{Mo})-\mathrm{IV}(\mathrm{Au}+\mathrm{Ba})-\mathrm{Tl}-\mathrm{Ni}-\mathrm{Sn}-\mathrm{As}-\mathrm{V}(\mathrm{Se}+\mathrm{Mn}+\mathrm{V})-\mathrm{Cr}-\mathrm{Cd}$ \\
\hline
\end{tabular}

Постседиментационные разновидности халькопирита развиты в мелкообломочных рудокластических слоях и околорудных сульфидсодержащих осадках в виде слоев, сегрегаций, кайм, прожилков, линз и конкреций. Находки новообразованного халькопирита в рудокластитах являются ярким подтверждением того, что процессы минералообразования продолжаются и после седиментации рудокластических потоков. Предполагается, что одним из ранних проявлений постседиментационных процессов в рудокластитах выступает замещение колломорфных и зернистых агрегатов пирита псевдоморфным халькопиритом. Псевдоморфная разновидность халькопирита наследует от пирита не только микроэлементный состав, но и форму агрегатов, очертания которых повторяют зерна гидротермального пирита (рис. 4, б). Замещение сульфидных рудокластов тонкозернистыми агрегатами халькопирита широко распространено как в рудах древних колчеданных залежей, так и в отложениях современных сульфидных построек, и связывается, как правило, с процессами раннего диагенеза $[4,9,10$, 33]. Сульфидные рудокласты характеризуются различной степенью развития псевдоморфного халькопирита, что может указывать на то, что халькопирит частично заместил пиритовые агрегаты еще до попадания в осадок.

Цементационный халькопирит формирует ткань сульфидных турбидитов, обрастает и образует прожилки в агрегатах пирита и псевдоморфного халькопирита. Видимого замещения цементационным халькопиритом сульфидных рудокластов при этом не зафиксировано. На Юбилейном месторождении относительное количество халькопиритового цемента возрастает в кровле слоев сульфидных турбидитов [25].
Аналоги данной разновидности халькопирита на колчеданных месторождениях Урала могут развиваться по агрегатам сфалерита в стадию позднего диагенеза, а также образуют прожилки, линзы и основную цементирующую массу $[4,10]$. Цементационный халькопирит в рудокластитах Юбилейного месторождения, как и других колчеданных залежах Урала, выступает одним из главных концентраторов редкой минерализации, включающей в себя разнообразные теллуриды, селениды, сульфосоли и самородное золото [10].

Постседиментационные процессы преобразования сульфидсодержащих осадков включают в себя образование сульфидных конкреций, широко распространенных в диагенетически преобразованных разновидностях тонко- и мелкообломочных колчеданных руд [9]. В последние годы появились работы по изучению минерального состава и геохимических особенностей конкреций пирита зонального строения в рудоконтролирующих горизонтах колчеданных залежей [34]. В отличие от конкреций пирита, изученные конкреции халькопирита характеризуются меньшим размером, отсутствием зонального строения и характерной шаровидной и эллипсовидной внешней морфологией. Более того, конкреции халькопирита развиты только в хлорит-кремнистых слоях и не формируют срастаний с прочими разновидностями халькопирита, из-за чего затруднительно определить их место в последовательности минералообразования. Тем не менее предполагается, что образование конкреций и цементационного халькопирита было сопряженным и является проявлением одного процесса, но в разных слоях. В пользу данного предположения говорят также их сходные геохимические особенности. 
Субгоризонтальные прожилки халькопирита и кварца в сульфидных слоях секут все прочие разновидности халькопирита и развиты, по-видимому, по трещинам кливажа. Считается, что полисинтетические двойники в крупнозернистом прожилковом халькопирите появляются под действием тектонических напряжений $[1,2]$. Аналоги подобной динамометаморфической разновидности халькопирита установлены как на неметаморфизованных [4], так и метаморфизированных [35] колчеданных месторождениях Урала.

Для постседиментационных разновидностей халькопирита, даже в большей степени, чем для гидротермальных, характерна контрастная дифференциация содержаний элементов-примесей. По положению медианных содержаний на диаграммах «box\&whiskers» заметно снижение концентраций V, $\mathrm{Mn}, \mathrm{Co}, \mathrm{Ni}, \mathrm{As}, \mathrm{Sb}, \mathrm{Te}, \mathrm{Au}, \mathrm{Tl}, \mathrm{Pb}$ и $\mathrm{Bi}$ в ряду постседиментационных сульфидов от псевдоморфного к цементационному, конкреционному и прожилковому халькопириту. Подобный тренд на снижение медианных значений концентраций характерен для примесей $\mathrm{Sb}, \mathrm{Bi}$ и $\mathrm{Pb}$, но только в ограниченном ряду псевдоморфный $\rightarrow$ цементационный $\rightarrow$ конкреционный халькопирит. Заметно, что новообразованный халькопирит, по сравнению с гидротермальным, значительно обеднен оловом. В целом концентрации большинства химических элементов в некоторых разностях постседиментационного халькопирита сопоставимы или выше, чем в гидротермальных аналогах. Одной из причин подобного обогащения новообразованного халькопирита может являться наследование элементов-примесей из растворяющихся рудокластов [9] Относительно высокие концентрации Со и $\mathrm{Ni}$ в халькопирите сульфидных турбидитов и конкреций могут быть связаны с поступлением этих элементов из базальтовой гиалокластики [9].

Микровключения редких минералов характерны как для гидротермальных, так и для постседиментационных разновидностей халькопирита. В крустификационном халькопирите палеокурильщиков кварцпирит-халькопиритового и кальцит-сфалерит-пиритхалькопиритового состава встречаются микровключения колорадоита, теллуровисмутита, гессита и штютцита, часто ассоциирующие с зернами самородного золота и электрума [25]. Более разнообразные ассоциации редких минералов обнаружены в постседиментационных разновидностях халькопирита. В псевдоморфном и цементационном халькопирите сульфидных турбидитов определены: самородное золото, колорадоит, гессит, алтаит, петцит, калаверит, штютцит, волынскит и минералы серии теллуровисмутит-раклиджит [25]. Конкреции халькопирита содержат микровключения самородного золота, гессита, петцита, колорадоита, алтаита, волынскита и минералов серии теллуровисмутит-раклиджит, часто образующих взаимные срастания. Для прожилкового динамометаморфического халькопирита включения самородного золота и теллуридов не характерны.

Предполагается, что формирование постседиментационных разновидностей халькопирита в процессе аутигенеза рудокластитов происходило под воздействием нисходящих морских вод без или при незначительном участии гидротермальных флюидов [4, 10, 33]. Наличие гиалокластического материала в сульфидных отложениях Юбилейного месторождения могло играть роль катализатора и способствовало замещению пиритовых рудокластов халькопиритом. По-видимому, именно влияние морской воды, гиалокластики и примеси осадков способствовало установлению в сульфидных осадках субщелочных условий, благоприятных для формирования постседиментационного халькопирита [9]. Образование халькопирита в сульфидных турбидитах относится к процессу аутигенеза и происходило в несколько стадий, в ходе которых в рудообразующем растворе происходило снижение концентрации химических элементов. В целом по степени взаимодействия с морской водой описанные рудокластиты можно отнести к зрелым [9].

\section{Заключение}

В колчеданных рудах Юбилейного месторождения дана минералого-геохимическая характеристика гидротермальной разновидности халькопирита, включающая халькопирит пирит-халькопиритовых (chp-1bs), сфалерит-пирит-халькопиритовых (chp-1gs) и халькопирит-пирит-сфалеритовых (chplws) труб палеокурильщиков, и постседиментационной разновидности сульфидных турбидитов, содержащей псевдоморфный (chp-2), цементационный (chp-3), конкреционный (chp-3nod) и прожилковый (chp-4) халькопирит сульфидных турбидитов. Перечисленные разновидности халькопирита составляют ряды, в которых закономерно изменяются минеральные, текстурноструктурные и геохимические характеристики. В гидротермальной группе в ряду от пиритхалькопиритовых к существенно сфалеритовым трубам палеокурильщиков наблюдается смена копьевидных и дендритовидных кристаллов халькопирита на графические агрегаты халькопирита и сфалерита. Текстурно-структурные различия в постседиментационных разновидностях халькопирита связаны с возрастанием крупности зерен и появлением полисинтетических двойников. В ряду гидротермальных разновидностей халькопирита снижаются медианные содержания примесей $\mathrm{Sb}, \mathrm{Tl}, \mathrm{Se}, \mathrm{Te}, \mathrm{Bi}, \mathrm{Pb}$, а в постседиментационной группе понижаются концентрации Mn, Co, Ni, Mo, As, Tl, Au, Ag, Pb, Bi, Tе и V. Сравнительный минералого-геохимический анализ халькопирита различного происхождения применительно к колчеданным залежам Урала проведено впервые.

В разновидностях халькопирита обнаружены микровключения редких минералов, разнообразие и количество находок которых в постседиментационной группе больше, чем в гидротермальной. Исключением выступает прожилковый динамометаморфический халькопирит, для которого микровключения не характерны. Рассчитанные геохимические ассоциации элементов-примесей также отражают наличие в разновидностях халькопирита микровключений самородного золота и теллуридов ( $\mathrm{Te}+\mathrm{Ag}+\mathrm{Au})$, связанных в том числе с включениями сфалерита $(\mathrm{Zn}+\mathrm{Cd}+\mathrm{Te}+\mathrm{Bi}+\mathrm{Ag})$ и 
пирита $(\mathrm{As}+\mathrm{Co}+\mathrm{Ni}+\mathrm{Tl}+\mathrm{Au})$. Устойчивую связь в халькопирите образуют элементы самостоятельных включений пирита $(\mathrm{As}+\mathrm{Co}+\mathrm{Mn}+\mathrm{Tl})$, галенита $(\mathrm{Pb}+\mathrm{Bi}+\mathrm{Se})$ и силикатов $(\mathrm{Mg}+\mathrm{V}+\mathrm{Ni})$. Полученные данные демонстрируют широкую вариацию минеральногеохимического состава продуктов сульфидного аутигенеза в рудах колчеданных месторождений.

\section{СПИСОК ЛИТЕРАТУРЫ}

1. Ярош П.Я. Диагенез и метаморфизм колчеданных руд на Урале. - М.: Наука, 1973. -240 c.

2. Еремин Н.И. Дифференциация вулканогенного сульфидного оруденения. - М.: МГУ, 1983.- $256 \mathrm{c}$.

3. Масленникова С.П., Масленников В.В. Сульфидные трубы палеозойских «черных курильщиков» (на примере Урала). Екатеринбург; Миасс: УрО РАН, 2007. - 312 с

4. Сафина Н.П., Масленников В.В. Рудокластиты колчеданных месторождений Яман-Касы и Сафьяновское (Урал). - Миасс: УрO РAH, 2009. $-260 \mathrm{c}$

5. Дифференциация токсичных элементов в условиях литогенеза и техногенеза колчеданных месторождений / В.В. Масленников, И.Ю. Мелекесцева, С.П. Масленникова, А.В. Масленникова, Г.А. Третьяков, Н.Р. Аюпова, Н.П. Сафина, К.А. Филиппова, В.Н. Удачин, П.Г. Аминов, А.С. Целуйко. - Екатеринбург: РИО УрО РАН, 2016. - 368 с

6. Шадлун Т.Н. О некоторых срастаниях сульфидов, характерных для современных океанических и древних колчеданных руд // Геология рудных месторождений. - 1991. - № 4. C. $110-117$.

7. Oudin E., Constantinou G. Black smoker chimney fragments in Cyprus sulphide deposits // Nature. - 1984 - V. 308. - P. 349-353.

8. Скрипченко Н.С. Гидротермально-осадочные сульфидные руды базальтоидных формаций. - М.: Наука, 1972. - 217 с.

9. Масленников В.В. Седиментогенез, гальмиролиз и экология колчеданоносных палеогидротермальных полей (на примере Южного Урала). - Миасс: ИМин УрО РАН, 1999. - 348 с.

10. Mineralogical features of ore diagenites in the Urals massive sulfide deposits, Russia / V.V. Maslennikov, N.R. Ayupova, N.P. Safina, A.S. Tseluyko, I.Yu. Melekestseva, R.R. Large, R.J. Herrington, V.A. Kotlyarov, I.A. Blinov, S.P. Maslennikova, S.G. Tessalina // Minerals. - 2019. - V. 3. - P. 150

11. Butler I.B., Nesbitt R.W. Trace element distributions in the chalcopyrite wall of black smoker chimney: insights from laser ablation-inductively coupled plasma-mass spectrometry (LA-ICPMS) // Earth and Planetary Science Letters. - 1999. - V. 167. P. 335-345.

12. Chimneys in Paleozoic massive sulfide mounds of the Urals VMS deposits: mineral and trace element comparison with modern black, gray and clear smokers / V.V. Maslennikov, S.P. Maslennikova, R.R. Large, L.V. Danyushevsky, R.J. Herrington, N.R. Ayupova V.V. Zaykov, A.Yu. Lein, A.S. Tseluyko, I.Yu. Melekestseva, S.G. Tessalina // Ore Geology Review. - 2017. - V. 85. - P. 64-106.

13. Distribution and solubility limits of trace elements in hydrothermal black smoker sulfides: an in-situ LA-ICP-MS study C.C. Wohlgemuth-Ueberwasser, F. Viljoen, S. Petersen, C. Vorster // Geochimica et Cosmochimica Acta. - 2015 - V. 159 - P. 16-41

14. George L.L., Cook N.J., Ciobanu C.L. Partitioning of trace elements in co-crystallized sphalerite-galena-chalcopyrite hydrothermal ores // Ore Geology Reviews. - 2016. - V. 77. P. 97-116.

15. Trace elements in hydrothermal chalcopyrite / L.L. George, N.J. Cook, B.B.P. Crowe, C.L. Ciobanu // Mineralogical Magazine. - 2018. - V. 82. - P. 59-88.

16. A review of Te and Se systematics in hydrothermal pyrite from precious metal deposits: Insights into ore-forming processes / M. Keith, D.J. Smith, G.R.T. Jenkin, D.A. Holwell, M.D. Dey // Ore Geology Reviews. - 2018. - V. 96. - P. 269-282.

17. Trace element systematics of pyrite from submarine hydrothermal vents / M. Keith, F. Häckel, K.M. Haase, U. Schwarz-Schampera R. Klemd // Ore Geology Reviews. - 2016. - V. 72. - P. 728-745.

18. Trace element systematics and ore-forming processes in mafic VMS deposits: evidence from the Troodos ophiolite, Cyprus / A.J. Martin, M. Keith, I. McDonald, K.M. Haase, K.A. McFall,
Авторы благодарны Л.В. Данюшевскому за помощь в выполнении ЛА-ИСП-МС анализов, а также рецензенту за иенные замечания. Минералого-геохимические исследования халькопирита труб палеокурильшиков выполнены в рамках госбюджетного проекта ЮУ ФНЦ МиГ УрО РАН № АААA-A19-119061790049-3. Изучение конкрещий халькопирита поддержаны проектом РФФИ № 17-05-00854.

R. Klemd, C.J. MacLeod // Ore Geology Reviews. - 2019. V. 106. - P. 205-225.

19. Медноколчеданные месторождения Урала: геологическое строение / под ред. В.А. Прокина, Ф.П. Буслаева, М.И. Исмагилова, А.М. Дымкина, К.С. Иванова, Е.С. Контаря, Б.Д. Магадеева, Б.Е. Милецкого, А.П. Наседкина, В.М. Нечеухина, Б.А. Попова, Б.П. Потапенко, А.К. Рогожникова, И.Б. Серавкина, В.И. Федорова, Р.Г. Язеева, П.Я. Яроша - Свердловск: УрO РAH, 1988. - $241 \mathrm{c}$.

20. Вариолитовые бониниты бурибайского вулканического комплекса, Южный Урал: Химия минералов / А.М. Косарев, С.А. Светов, С.Ю. Чаженгина, Г.Т. Шафигуллина // Металлогения древних и современных океанов-2016: Материалы науч. конф. - Миасс, 25-29 апреля 2016. - Миасс: ИМинУрО РАН, 2016. - C. $35-38$.

21. Косарев А.М., Серавкин И.Б., Холоднов В.В. Геодинамические и петролого-геохимические аспекты зональности Магнитогорской колчеданоносной мегазоны на Южном Урале // Литосфера. - 2014. - № 2. - С. 3-25.

22. Бонинитовые вариолиты Бурибайского вулканического комплекса Южного Урала: минералогия, геохимия и условия образования / А.М. Косарев, С.А. Светов, С.Ю. Чаженгина, Г.Т. Шафигуллина // Литосфера. - 2018. - Т. 18. - № 2. C. $246-279$.

23. Серавкин И.Б. Корреляция состава руд и рудовмещающих пород в вулканогенных колчеданных месторождениях (на примере Южного Урала) // Геология рудных месторождений. - 2013. - Т. 55. - № 3. - С. 238-258.

24. Минералогические особенности руд медноколчеданного месторождения Юбилейное (Ю. Урал) / И.В. Викентьев, А.Г. Саенко, Е.В. Карелина, А.И. Ежов, Н.В. Трубкин // Вестник РУДН. Серия «Инженерные исследования». - 2011. № 1. - С. $84-89$.

25. Теллуридная минерализация в обломочных рудах медноколчеданного месторождения Юбилейное (Южный Урал) / А.С. Целуйко, В.В. Масленников, Н.Р. Аюпова, С.П. Масленникова, Л.В. Данюшевский // Геология рудных месторождений. - 2019. - Т. 61. - № 2. - С. 40-71.

26. Routine quantitative multi-element analysis of sulphide minerals by laser ablation ICP-MS: Standard development and consideration of matrix effect / L. Danyushevsky, P. Robinson, S. Gilbert, M. Norman, R., Large P. McGoldrick, M. Shelley // Geochemistry: Exploration, Environment, Analysis. - 2011. V. 11. - P. 51-60.

27. Гидротермальный рудогенез океанского дна / Ю.А. Богданов, А.П. Лисицын, А.М. Сагалевич, Е.Г. Гурвич. - М.: Наука, 2006. $-527 \mathrm{c}$.

28. Смирнов В.И. Корреляционные методы при парагенетическом анализе - М.: Недра, 1981. - 174 c.

29. Haymon R.M. Growth history of hydrothermal black smoker // Nature. - 1983. - V. 301. - P. 695-698.

30. Janecky D.R., Seyfried W.F. Jr. Formation of massive sulfide deposits on oceanic ridge crasts: incremental reaction models for mixing between hydrothermal solutions and sea water // Geochimica et Cosmochimica Acta. - 1984. - V. 48. P. $2723-2738$

31. Graham U.M., Bluth G.J., Ohmoto H. Sulfidesulfate chimneys on the East Pacific Rise, $11^{\circ}$ and $13^{\circ} \mathrm{N}$ latitude. Part 1: Mineralogy and paragenesis // Canadian Mineralogist. - 1988. - V. 26. P. 487-504.

32. Tivey M.K. The influence of hydrothermal fluid composition and advection rates on black smoker chimney mineralogy: Insights from modeling transport and reaction // Geochimica et Cosmochimica Acta - 1995. - V. 59 - P. 1933-1949. 
33. Девонские рудокластические турбидиты на примере медноколчеданного месторождения «Молодежное» (Южный Урал)/ В.Ю. Русаков, Б.Н. Рыженко, И.А. Рощина, Н.Н. Кононкова, B.С. Карпухина // Геохимия. - 2015. - № 7. - С. 624-650.

34. Genna D., Gaboury D. Deciphering the hydrothermal evolution of a VMS system by LA-ICP-MS using trace elements in pyrite: an example from the Bracemac-McLeod deposits, Aditibi, Canada, and implication for exploration // Economic Geology. - 2015. V. 110. - P. 2087-2108.

35. Metamorphism of volcanogenic massive sulphide deposits in the Urals / I.V. Vikentyev, E.V. Belogub, K.A. Novoselov, V.P. Moloshag // Ore Geology Reviews. - 2017. - V. 85. - P. 30-63.

Поступила 03.06.2020 г.

\section{Информация об авторах}

Целуйко A.C., младший научный сотрудник лаборатории минералогии рудогенеза Института минералогии Южно-Уральского федерального научного центра минералогии и геоэкологии УрО РАН.

Масленников В.В., доктор геолого-минералогических наук, профессор, член-корреспондент, главный научный сотрудник лаборатории минералогии рудогенеза Института минералогии Южно-Уральского федерального научного центра минералогии и геоэкологии $У p O P A H$.

Аюnова H.P., кандидат геолого-минералогических наук, ведущий научный сотрудник лаборатории минералогии рудогенеза Института минералогии Южно-Уральского федерального научного центра минералогии и геоэкологии УрО РАН.

Масленникова С.П., кандидат геолого-минералогических наук, старший научный сотрудник лаборатории минералогии рудогенеза Института минералогии Южно-Уральского федерального научного центра минералогии и геоэкологии УрО РАН.

Артемьев Д.А., кандидат геолого-минералогических наук, научный сотрудник лаборатории минералогии рудогенеза Института минералогии Южно-Уральского федерального научного центра минералогии и геоэкологии УрО РАН.

Блинов И.А., кандидат геолого-минералогических наук, научный сотрудник лаборатории минералогии рудогенеза Института минералогии Южно-Уральского федерального научного центра минералогии и геоэкологии УpO РAH. 
UDC 553.435

\title{
MINERALOGICAL AND GEOCHEMICAL FEATURES OF CHALCOPYRITE FROM THE YUBILEYNOE MASSIVE SULFIDE DEPOSIT (SOUTH URALS): LA-ICP-MS DATA
}

\author{
Aleksandr S. Tseluyko1, \\ celyukoa@rambler.ru \\ Valeriy V. Maslennikov ${ }^{1}$, \\ mas@mineralogy.ru \\ Nuriya R. Ayupova1, \\ aupova@mineralogy.ru \\ Svetlana P. Maslennikova ${ }^{1}$, \\ svmas@mineralogy.ru \\ Dmitry A. Artemyev', \\ artemyev@mineralogy.ru \\ Ivan A. Blinov' \\ Ivan_a_blinov@mail.ru \\ 1 South Urals Federal Research Center of Mineralogy and Geoecology of UB RAS, \\ territory of the llmeny State Reserve, Miass, 456317, Russia.
}

Relevance. The LA-ICP-MS analysis of sulfides is one of the promising directions in study of ore deposits. The understanding of mineralogical-geochemical evolution of sulfides allows interpretation of differentiation of components at stages of hydrothermal sedimentogenesis and further lithogenesis of massive sulfide deposits. This work is important for development of models of sulfide authigenesis.

The main aim of the research is to compare mineralogical-geochemical features of chalcopyrite types to identify the evolution of sulfide ores from the Yubileynoe massive sulfide deposit (South Urals).

Methods. The morphogenetic types of chalcopyrite were identified using ore-facial mapping in the open pit of the deposit. The mineralogical features of ores were studied under an Olympus BX51 optical microscope. The chemical composition of minerals was analyzed on a Tescan Vega 3 SBU scanning electron microscope equipped with an Oxford Instruments X-act energy dispersive analyzer. The trace element contents of chalcopyrite were determined using LA-ICP-MS on an Agilent 7700x mass spectrometer equipped with a New Wave Research UP-213 laser ablation device at the SU FRC MG UB RAS and University of Tasmania (Hobart, Australia).

Results. Chalcopyrite was subdivided into two genetic types: hydrothermal and post-sedimentary. The hydrothermal type includes subhedral chalcopyrite from chalcopyrite-pyrite, chalcopyrite-pyrite-sphalerite, and sphalerite-pyrite-chalcopyrite smoker chimneys. The post-sedimentary type of pseudomorphic, interstitial, nodular, and veinlet (dynamometamorphic) chalcopyrite is typical of clastic ore. Each chalcopyrite type is characterized by various mineral assemblages and trace element contents, reflecting different formation conditions. Themorphology of chalcopyrite changes from spear-like and dendritic crystals to graphic and epitaxial intergrowths of chalcopyrite and sphalerite in a range from chalcopyrite-pyrite to mostly sphalerite smoker chimneys. The median contents of high-temperature (Se, Bi), medium-temperature (Te, Sb) and low-temperature (TI) trace elements of hydrothermal chalcopyrite decrease in this range. The postsedimentary chalcopyrite has the lower Sn contents and exhibits minor variations in Se contents. The median Mn, Co, Ni, Mo, As, Tl, Au, $\mathrm{Ag}, \mathrm{Bi}$, and Te contents decrease in a consecutive range of post-sedimentary chalcopyrite: pseudomorphic $\rightarrow$ interstitial $\rightarrow$ nodular $\rightarrow$ veinlet.

Key words:

Chalcopyrite, authigenesis, LA-ICP-MS, smoker chimneys, sulfide turbidites, sulfide nodules, massive sulfide deposits, South Urals.

The research was financially supported by State Contract of the Institute of Mineralogy UB RAS project no. AAAA-016116021010244-0 and RFBR grant no. 18-45-700019.

\section{REFERENCES}

1. Yarosh P.Ya. Diagenez i metamorfizm kolchedannykh rud na Urale [Diagenesis and metamorphism of massive sulfide ores in the Urals]. Moscow, Nauka Publ., 1973. 240 p.

2. Eremin N.I. Differentsiatsiya vulkanogennogo sulfidnogo orudeneniya [Differentiation of volcanogenic massive sulfide mineralization]. Moscow, MSU Publ., 1983. 256 p.

3. Maslennikova S.P., Maslennikov V.V. Sulfidnye truby paleozoyskikh "chernykh kurilshchikov» (na primere Urala) [Paleozoic «black smoker» sulfide chimneys]. Yekaterinburg; Miass, UB RAS Publ., 2007. 312 p.

4. Safina N.P., Maslennikov V.V. Rudoklastity kolchedannykh mestorozhdeniy Yaman-Kasy i Safyanovskoe (Ural) [Ore clastites of the Yaman-Kasy and Saphyanovka VMS deposits (Ural)]. Miass, UB RAS Publ., 2008. 260 p.

5. Maslennikov V.V., Melekestseva I.Yu., Maslennikova S.P., Maslennikova A.V., Tretyakov G.A., Ayupova N.R., Safina N.P., Filippova K.A., Udachin V.N., Aminov P.G., Tseluyko A.S. Differentsiatsiya toksichnykh elementov $v$ usloviyakh litogeneza $i$ tekhnogeneza kolchedanykh mestorozhdeniy [Differentiation of toxic elements during lithogenesis and technogenesis of massive sulfide deposits]. Yekaterinburg, RIO UB RAS Publ., 2016. 368 p.

6. Shadlun T.N. Some intergrowths of sulfides in modern and ancient massive sulfide ores. Geology of Ore Deposits, 1991, vol. 33, pp. $110-118$.

7. Oudin E., Constantinou G. Black smoker chimney fragments in Cyprus sulphide deposits. Nature, 1984, vol. 308, pp. 349-353. 
8. Skripchenko N.S. Gidrotermalno-osadochnye sulfidnye rudy bazaltoidnykh formatsiy [Hydrothermal-sedimentary sulfide ores of basalt-like formations]. Moscow, Nauka Publ., 1972. 217 p.

9. Maslennikov V.V. Sedimentogenez, galmiroliz $i$ ekologiya kolchedanonosnykh paleogidrotermalnykh poley (na primere Yuzhnogo Urala) [Sedimentogenesis, halmyrolysis and ecology of massive sulfide paleohydrothermal fields]. Miass, Geotur Publ., 1999. $348 \mathrm{p}$.

10. Maslennikov V.V., Ayupova N.R., Safina N.P., Tseluyko A.S., Melekestseva I.Yu., Large R.R., Herrington R.J., Kotlyarov V.A., Blinov I.A., Maslennikova S.P., Tessalina S.G. Mineralogical features of ore diagenites in the Urals massive sulfide deposits, Russia. Minerals, 2019, vol. 3, pp. 150.

11. Butler I.B., Nesbitt R.W. Trace element distributions in the chalcopyrite wall of black smoker chimney: insights from laser ablation-inductively coupled plasma-mass spectrometry (LA-ICPMS). Earth and Planetary Science Letters, 1999, vol. 167, pp. 335-345.

12. Maslennikov V.V., Maslennikova S.P., Large R.R., Danyushevsky L.V., Herrington R.J., Ayupova N.R., Zaykov V.V., Lein A.Yu., Tseluyko A.S., Melekestseva I.Yu., Tessalina S.G. Chimneys in Paleozoic massive sulfide mounds of the Urals VMS deposits: mineral and trace element comparison with modern black, gray and clear smokers. Ore Geology Review, 2017, vol. 85, pp. 64-106.

13. Wohlgemuth-Ueberwasser C.C., Viljoen F., Petersen S., Vorster C. Distribution and solubility limits of trace elements in hydrothermal black smoker sulfides: an in-situ LA-ICP-MS study. Geochimica et Cosmochimica Acta, 2015, vol. 159, pp. 16-41.

14. George L.L., Cook N.J., Ciobanu C.L. Partitioning of trace elements in co-crystallized sphalerite-galena-chalcopyrite hydrothermal ores. Ore Geology Reviews, 2016, vol. 77, pp. 97116

15. George L.L., Cook N.J., Crowe B.B.P., Ciobanu C.L. Trace elements in hydrothermal chalcopyrite. Mineralogical Magazine, 2018 , vol. 82, pp. 59-88.

16. Keith M., Smith D.J., Jenkin G.R.T., Holwell D.A., Dey M.D. A review of $\mathrm{Te}$ and Se systematics in hydrothermal pyrite from precious metal deposits: Insights into ore-forming processes. Ore Geology Reviews, 2018, vol. 96, pp. 269-282.

17. Keith M., Häckel F., Haase K.M., Schwarz-Schampera U., Klemd R., Trace element systematics of pyrite from submarine hydrothermal vents. Ore Geology Reviews, 2016, vol. 72, pp. 728-745.

18. Martin A.J., Keith M., McDonald I., Haase K.M., McFall K.A., Klemd R., MacLeod C.J. Trace element systematics and oreforming processes in mafic VMS deposits: evidence from the Troodos ophiolite, Cyprus. Ore Geology Reviews, 2019, vol. 106, pp. 205-225.

19. Mednokolchedanye mestorozhdeniya Urala: geologicheskoe stroenie [Massive sulfide deposits of the Urals: geological structure]. Eds. V.A. Prokin, F.P. Buslaev, M.I. Ismagilov A.M. Dymkin, K.S. Ivanov, E.S. Kontar, B.D. Magadeev, B.E. Mileckij, A.P. Nasedkin, V.M. Necheuhin, B.A. Popov, B.P. Potapenko, A.K. Rogozhnikov, I.B. Seravkin, V.I. Fedorov, R.G. Yazeev, P.Ya. Yarosh. Sverdlovsk, UB AS USSR Publ., 1988. 241 p.

20. Kosarev A.M., Svetov S.A., Chazhengina S.Yu., Shafigullina G.T Variolitovye boninity buribayskogo vulkanicheskogo kompleksa, Yuzhny Ural: khimiya mineralov [Variolite boninites of the Buribay volcanic complex, South Urals: mineral chemistry]. Metallogeneia drevnikh $i$ sovremennykh okeanov-2016
[Metallogeny of ancient and modern oceans-2016]. Miass, IMin UB RAS Publ., 2016. pp. 35-38.

21. Kosarev A.M., Seravkin I.B., Kholodnov V.V. Geodinamic, petrological and geochemical aspects of zoning Magnitogorsk pyrite Megazone in Southern Ural. Litosphera, 2014, vol. 2, pp. 325. In Rus.

22. Kosarev A.M., Svetov S.A., Chazhengina S.Yu., Shafigullina G.T. Boninitic variolites of the Buribay volcanic complex the Southern Urals: mineralogy, geochemistry and formation conditions. Litosphera, 2018, vol. 18, pp. 246-279. In Rus.

23. Seravkin I.B. Correlation between compositions of ores and host rocks in volcanogenic massive sulfide deposits of the Southern Urals. Geology of Ore Deposit, 2013, vol. 55, pp. 207-224.

24. Vikentyev I.V., Saenko A.G., Karelina E.V., Ezhov A.I., Trubkin N.V. Mineralogical features of ore of copper-pyritic deposit Yubileinoe (S. Urals). Vestnik RUDN, seria Inzhenernye issledovania, 2011, no 1, pp. 84-89. In Rus.

25. Tseluyko A.S., Maslennikov V.V., Ayupova N.R., Maslennikova S.P. Danyushevsky L.V. Tellurium-bearing mineralization in clastic ores at the Yubileynoe copper massive sulfide deposit (Southern Urals). Geology of Ore Deposits, 2019, vol. 61, pp. 40-71.

26. Danyushevsky L., Robinson P., Gilbert S., Norman M., Large R., McGoldrick P., Shelley M. Routine quantitative multi-element analysis of sulphide minerals by laser ablation ICP-MS: Standard development and consideration of matrix effect. Geochemistry: Exploration, Environment, Analysis, 2011, vol. 11, pp. 51-60.

27. Bogdanov Yu.A., Lisitsyn A.P., Sagalevich A.M., Gurvich E.G. Gidrotermalny rudogenez okeanskogo dna [Hydrothermal ore genesis of the ocean floor]. Moscow, Nauka Publ., 2006. 527 p.

28. Smirnov V.I. Korrelyatsionnye metody pri parageneticheskom analize [Correlation methods in paragenetic analysis]. Moscow, Nedra Publ., 1981. 174 p.

29. Haymon R.M. Growth history of hydrothermal black smoker. Nature, 1983, vol. 301, pp. 695-698.

30. Janecky D.R., Seyfried W.F. Jr. Formation of massive sulfide deposits on oceanic ridge crasts: incremental reaction models for mixing between hydrothermal solutions and sea water. Geochimica et Cosmochimica Acta, 1984, vol. 48, pp. 2723-2738.

31. Graham U.M., Bluth G.J., Ohmoto H. Sulfidesulfate chimneys on the East Pacific Rise, $11^{\circ}$ and $13^{\circ} \mathrm{N}$ latitude. Part 1: Mineralogy and paragenesis. Canadian Mineralogist, 1988, vol. 26, pp. 487-504.

32. Tivey M.K. The influence of hydrothermal fluid composition and advection rates on black smoker chimney mineralogy: insights from modeling transport and reaction. Geochimica et Cosmochimica Acta, 1995, vol. 59, pp. 1933-1949.

33. Rusakov V.Y., Ryzhenko B.N., Roshchina I.A., Kononkova N.N., Karpukhina V.S. Devonian ore clastic turbidites of the Molodezhnoe massive copper sulfide deposit, Southern Urals. Geochemistry International, 2015, vol. 53, pp. 624-650. In Rus.

34. Genna D., Gaboury D. Deciphering the hydrothermal evolution of a VMS system by LA-ICP-MS using trace elements in pyrite: an example from the Bracemac-McLeod deposits, Aditibi, Canada, and implication for exploration. Economic Geology, 2015, vol. 110, pp. 2087-2108.

35. Vikentyev I.V., Belogub E.V., Novoselov K.A., Moloshag V.P. Metamorphism of volcanogenic massive sulphide deposits in the Urals. Ore Geology Reviews, 2017, vol. 85, pp. 30-63.

Received: 3 June 2020.

\section{Information about the authors}

Aleksandr S. Tseluyko, junior researcher, South Urals Federal Research Center of Mineralogy and Geoecology of UB RAS.

Valeriy V. Maslennikov, Dr. Sc., professor, correspondent member, chief researcher, South Urals Federal Research Center of Mineralogy and Geoecology of UB RAS.

Nuriya R. Ayupova, Cand. Sc., leading researcher, South Urals Federal Research Center of Mineralogy and Geoecology of UB RAS.

Svetlana P. Maslennikova, Cand. Sc., senior researcher, South Urals Federal Research Center of Mineralogy and Geoecology of UB RAS.

Dmitry A. Artemyev, Cand. Sc., researcher, South Urals Federal Research Center of Mineralogy and Geoecology of UB RAS. Ivan A. Blinov, Cand. Sc., researcher, South Urals Federal Research Center of Mineralogy and Geoecology of UB RAS. 